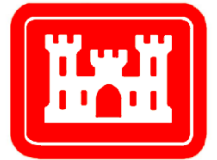

US Army Corps of Engineers $S_{\circledast}$

Engineer Research and

Development Center

\title{
FEDC
}

Dredging Operations and Environmental Research Program

\section{Barriers to Innovation in USACE}

Matthew D. Wood, Sabrina Larkin, Emily Wells,

September 2020

Igor Linkov and Todd S. Bridges

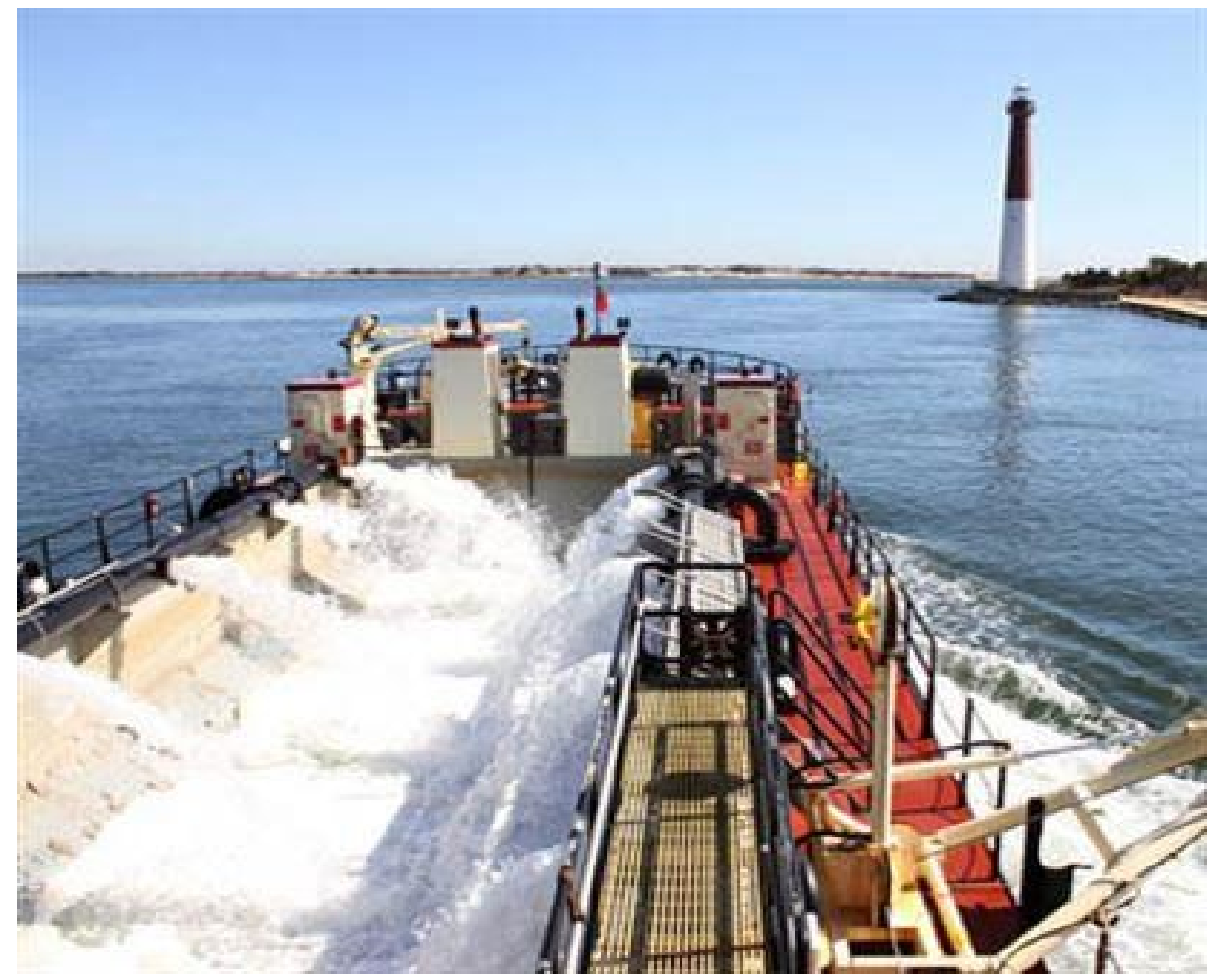

Approved for public release; distribution is unlimited. 
The US Army Engineer Research and Development Center (ERDC) solves the nation's toughest engineering and environmental challenges. ERDC develops innovative solutions in civil and military engineering, geospatial sciences, water resources, and environmental sciences for the Army, the Department of Defense, civilian agencies, and our nation's public good. Find out more at www.erdc.usace.army.mil.

To search for other technical reports published by ERDC, visit the ERDC online library at https://erdclibrary.on.worldcat.org/discovery.

Cover Photo by Tim Boyle

MURDEN clears shoaling from Barnegat Inlet, NJ (2014) 


\section{Barriers to Innovation in USACE}

Matthew D. Wood, Sabrina Larkin, Emily Wells, Igor Linkov, and Todd S. Bridges

Environmental Laboratory

US Army Engineer Research and Development Center

3909 Halls Ferry Road

Vicksburg, MS 39180-6199

Final report

Approved for public release; distribution is unlimited.

Prepared for US Army Corps of Engineers

Washington, DC 20314

Under Funding Account Code U4368804, AMSCO Code 089500, “Mental Modeling Decision Tools" 


\section{Abstract}

The Dredging Operations and Environmental Research Program (DOER) of the United States Army Corps of Engineers (USACE) develops new tools and practices to support the efficiency, effectiveness, and sustainability of navigation dredging operations and then implements these new approaches (that is, innovations). We analyzed the innovation process to increase the adoption and implementation of new approaches and techniques. We then created a literature review of innovation diffusion theories and developed a mental model that identifies the actual and perceived barriers to innovation diffusion in USACE through a case study of its Navigation Program. We built the final expert mental model using interviews with 25 subject matter experts familiar with the program's processes and external stakeholders. Interviewees reported environmental and budgetary constraints, time restrictions, and politics as the most common barriers to dredging innovation, including those based on the perceptions and beliefs of stakeholders rather than hard engineering or policy constraints (herein cognitive barriers). We suggest overcoming these barriers through changes in communication channels and social systems, such as public outreach through social media channels; interpersonal faceto-face meetings with decision makers; internal collaboration between local USACE districts and external collaboration with outside stakeholders, such as contractors and environmental regulators.

DISCLAIMER: The contents of this report are not to be used for advertising, publication, or promotional purposes. Citation of trade names does not constitute an official endorsement or approval of the use of such commercial products. All product names and trademarks cited are the property of their respective owners. The findings of this report are not to be construed as an official Department of the Army position unless so designated by other authorized documents. 


\section{Contents}

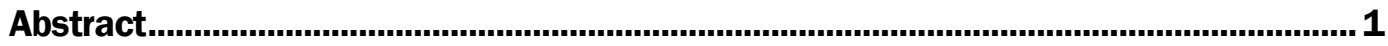

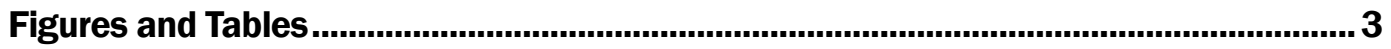

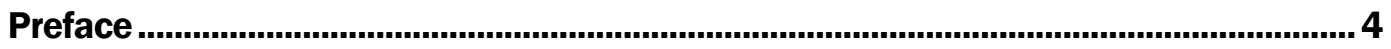

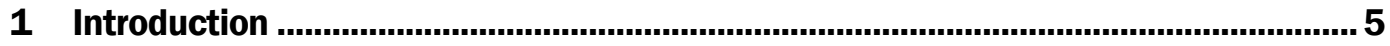

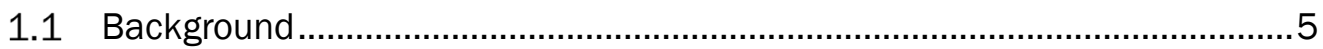

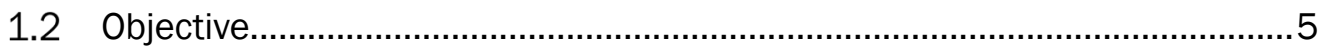

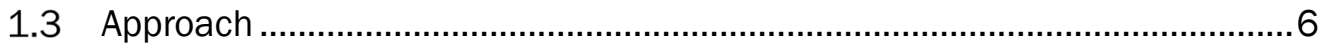

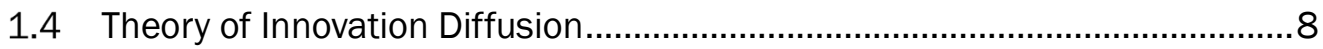

1.5 Examples of technology transition and adoption .................................... 12

1.5.1 Sample Innovation Diffusion studies .................................................................... 13

1.5.2 Sample Innovation Diffusion in government ...................................................... 16

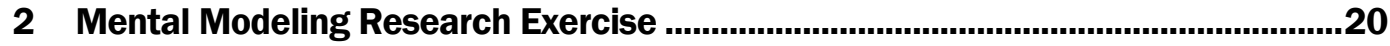

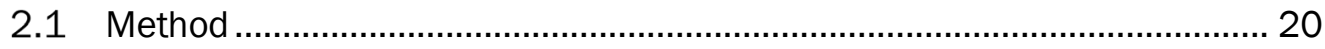

2.1.1 Influence diagram development .................................................................... 21

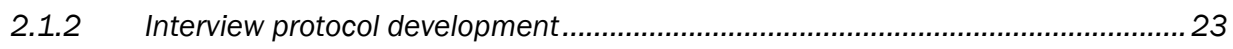

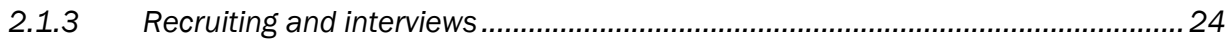

3 Results...................................................................................................................26

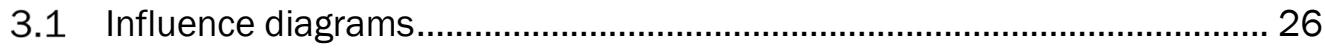

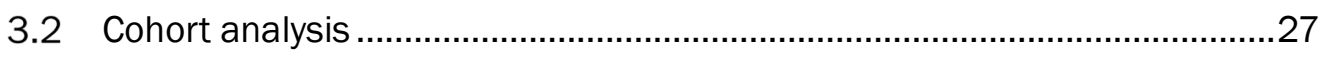

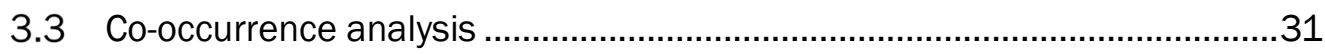

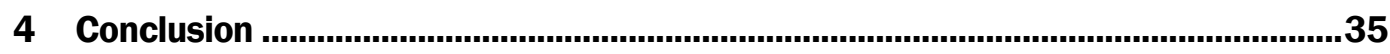

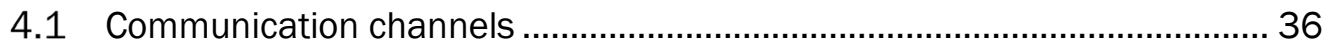

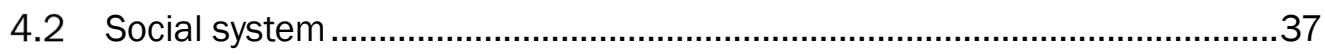

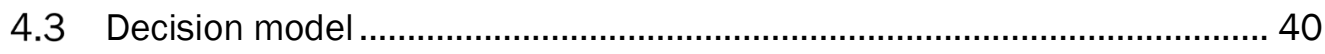

4.4 Further considerations for innovation within USACE.................................41

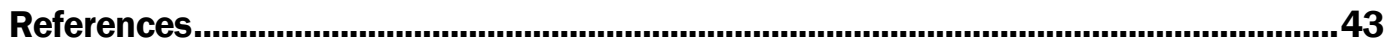

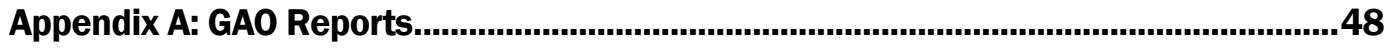

Appendix B: Category Definitions ............................................................................................49

Appendix C: Interview Protocol ..............................................................................

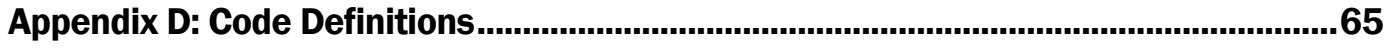

Report Documentation Page 


\section{Figures and Tables}

\section{Figures}

Figure 1. Diffusion of an innovation across the population of adopters as a function of time (AtKisson 2017, modified from Rogers 2003, 112).

Figure 2. Adoption categorization on the basis of innovativeness (Rogers 2003, 171).

Figure 3. Number of reports that mention factors contributing to adoption of innovation. Number reported reflects the count of reports across 37 total reports that mention each factor. Counts are inclusive if the report mentions more than one factor.

Figure 4. Simple mental model of Navigation O\&M Program innovation. ..........................22

Figure 5. Draft expert mental model of cognitive barriers to innovation in Navigation Operations and Maintenance (Nav O\&M).

Figure 6. Summary of interview protocol.

Figure 7. Final expert mental model of navigation.

Figure 8. Decision model for effective innovation transition strategy designed for USACE

\section{Tables}

Table 1. List of organizations represented in interviews. 25

Table 2. Highest-weighted codes from each interviewee group and their weights. .29

Table 3. Most highly weighted arrows in all interviewee groups...........................................33

Table 4. Highly weighted arrows by frequency. 


\section{Preface}

This study was conducted for the US Army Corps of Engineers, Dredging Operations and Environmental Research Program under Funding Account Code U4368804, AMSCO Code 089500, "Mental Modeling Decision Tools.” The technical monitor was Dr. Todd Swannack.

The work was performed by the Environmental Risk Assessment Branch of the Environmental Processes and Engineering Division, US Army Engineer Research and Development Center, Environmental Laboratory. At the time of publication, Mr. Jay Lindsay was Chief, Environmental Risk Assessment Branch; Mr. Warren Lorentz was Chief, Environmental Processes and Engineering Division; and Dr. Todd Bridges was the Dredging Operations and Environmental Research Program Manager. The Deputy Director of the Environmental Laboratory was Dr. Jack E. Davis, and the Director was Dr. Edmond J. Russo Jr.

The Commander of ERDC was COL Teresa A. Schlosser and the Director was Dr. David W. Pittman. 


\section{Introduction}

\subsection{Background}

The United States Army Corps of Engineers (USACE) faces a number of challenges as an engineering organization that owns and operates hundreds of billions of dollars in water resources infrastructure. Most of the initial investments and construction projects producing this infrastructure occurred many decades in the past, resulting in the current need to support, repair, rehabilitate, and extend its useful life. For example, the Federal Harbor Maintenance Trust Fund revenues have been chronically used for purposes (for example, federal deficit offsets) other than the navigation maintenance activities for which it was established and as a result has left maintenance activities chronically underfunded and unexecuted. Baseline needs for capital improvements to American freight infrastructure, including inland navigation from coastal ports, are assessed at $\$ 29$ billion through 2020, yet projected spending is currently $\$ 11$ billion (ASEE 2017). Technical constraints such as throughput limits on dredging equipment and ever-changing economic, demographic, and political conditions produce new social contexts, needs, and requirements. The evolution of environmental regulations and requirements over the last 50 years has created a range of constraints and costs that directly impact the execution of USACE's missions and operations. For example, seasonal restrictions and environmental windows, periods when maintenance and improvement activity is allowed or restricted, exists for many species along federal navigation projects. Regulations often permit dredging only during the winter months, leading to project delays because of poor weather. Other restrictions may exist for the type of equipment allowed, which can increase project timelines and costs (Dickerson Reine, and Clarke 1998; Mitchell and Nachtmann 2016).

\subsection{Objective}

These conditions, among others, require USACE to innovate by developing and applying new science, technology, and engineering practices to successfully execute its enduring missions in the face of mounting budgetary, environmental, and stakeholder constraints. This need raises a number of questions about innovation:

- How does USACE accomplish innovation? 
- How are these processes informed by policy and then resourced by USACE?

- What incentive structures support innovation throughout USACE?

- What metrics measure USACE's progress in innovation?

- What barriers to innovation exist, and how can these barriers be addressed?

The USACE Navigation Program provides a useful context for exploring the importance of innovation and the barriers that exist to innovation. The program is responsible for maintaining the navigability of the nation's coastal and inland waterways, which includes almost $40,000 \mathrm{~km}$ of navigation channels. USACE fulfills this navigation mission in part by dredging channels and harbors so that they remain safe and efficient for navigation. Navigation dredging is a large activity for the USACE: 150-225 million cubic meters of sediment moved annually, with a budget of $\$ 1$ billion (USACE National Data Center 2016). The combined effect of global economic trends; the movement of commercial goods; the development of new infrastructure systems (for example, expansion of the Panama Canal); the increasing size and draft of commercial vessels; limited space and facilities for managing dredged material; the demand for beneficial use of sediments to support aquatic ecosystems and resilience; and the increasing number of both federal and state regulatory requirements on dredging creates a wide-reaching and urgent need to adapt and improve execution of the dredging program. As such, the questions informing the present study were (1) what barriers to innovation exist and (2) how to address them.

\subsection{Approach}

Within the USACE Navigation Program, we focused specifically on dredging activities in its Operations and Maintenance Program (Nav O\&M) as an initial exploration of innovation barriers relevant to USACE, since maintenance dredging is one of the largest components of Nav O\&M. We hypothesized that transition obstacles are not fundamental to the technology development cycle or Nav O\&M but rather result from a combination of factors, including perceptions about the applicability and utility (or lack thereof) of research products available to the program. In order to reduce barriers to innovation and technology transition, especially the cognitive barriers (perceived obstacles to innovation and technology transition), we conducted a mental models research exercise to identify and potentially mitigate these barriers using the navigation business line as the problem 
context. Navigation represents one of the largest mission areas for USACE, both in terms of importance and spending. It is nearly $25 \%$ of the $\$ 4.6$ billion USACE Civil Works Budget (USACE 2017).

Mental model influence diagrams represent how individuals perceive something: a risk, a technology, a process. Mental models bridge the gap between physical and social sciences by facilitating researchers' understanding of how experts and laypersons perceive some subject matter (Morgan et al. 2002). Mental models lend understanding to a variety of engineering and organizational change problems for USACE, such as understanding perception of flood risk management processes (Wood, Kovacs, et al. 2012, 1350) and the ability to adapt in the face of climate change (Bridges et al. 2013) or identifying opportunities for business development and growth (Collier, Trump, et al. 2016; Wood et al. 2017). Outside of USACE, mental models have helped develop effective risk communications (Atman et al. 1994) and risk management (Stewart and Butte 2017; Wagner 2007), effective decision support systems for hazardous material exposure (Kovacs, Thorne, and Butte 2017), effective natural resource management strategies (Jones et al. 2011; Wood, Bostrom, et al. 2012), and effective development and evaluation frameworks for a wide range of policies (Wood et al. 2017; Kane and Trochim 2007).

In the current study, we created mental model-influence diagrams using interviews with individuals familiar with the USACE dredging processes and organization. This sample of participants came from a variety of domain expertise backgrounds and stakeholder groups and represented the perspectives of USACE, other government agencies, nonprofit organizations with an interest in navigation (including environmental groups), and dredging contractors. Interviews were conducted in person or by phone, and interviewees were selected through a combination of convenience and snowball sampling. Interviewers asked participants for their observations and recommendations for improvements to dredging innovation, operation, and management. A comprehensive review of how federal agencies in the transportation or regulatory sectors have dealt with barriers to innovation augmented the interview responses in order to identify strategies to overcome interviewee-identified barriers.

We then synthesized information from the mental models and literature review to create as comprehensive a view of the problem as possible. We 
also provide recommendations on potential courses of action to reduce barriers to innovation and technology transfer.

\subsection{Theory of Innovation Diffusion}

Rogers (2003) explores the processes, motivations, and rate at which innovations diffuse through a social system, from the development of an innovation to its widespread implementation. The concept of diffusion was first studied in the 1950s in the context of agriculture technology and rural sociology, as anthropologists and geographers studied how farmers communicated and adopted innovations in hybrid seeds, equipment, and techniques (Rogers 2003). Rogers published his first work on his innovation diffusion theory in 1962 to describe the broad adoption of agricultural technologies (Rogers 2003). The theory now spans societies and sectors and details the elements, processes, and rates of adoption of successful innovation diffusion. For this case study, we chose Rogers's innovation diffusion theory as the framework.

Rogers (2003) outlines four main elements of innovation diffusion theory, which Rogers defines as "the process by which an innovation is communicated through certain channels over time among the members of a social system" (35). The theory describes how the perceived attributes of the innovation affect the rate of adoption (221). Innovations are measured on five criteria, the two most critical of which are relative advantage, or how much more effective the innovation is, and compatibility, or how consistently the innovation meets existing values and needs. These two primary criteria should be considered alongside three others: complexity, or how difficult the innovation is to understand; trialability, or how easily the innovation can be trialed before full implementation; and observability, or how observable the results of the innovation are to stakeholders.

Rogers's theory posits that communication is the process of participants creating and sharing information to develop a common formulation. Diffusion is a subtype of communication, defined as conveying information about new ideas. Thus, the communication process in this context involves the creation of a channel between two people for the purpose of sharing information about the innovation. One of these people has knowledge of the innovation, and one does not; the channel then becomes the mechanism through which knowledge of the innovation moves from one person to the next. Mass media channels are an effective way to generate awareness 
about a new innovation, especially to the general public. However, to convince a specific individual or decision maker to adopt a new approach, interpersonal channels that feature face-to-face interactions are more compelling (Rogers 2003, 205). Innovations are even more likely to be adopted and implemented through these interpersonal communication channels when the individuals presenting the innovation and the potential adopter share similarities in expertise, education, socioeconomic background, or other factors (Rogers 2003). Homophily, or the sharing of similar characteristics, supports a foundational trust between two people, because the individuals likely share common meanings of subcultural language, knowledge, attitude, and behavior. Homophily, therefore, increases the likelihood that the innovation will be adopted and implemented (Rogers 2003, 305).

Rogers's theory also considers innovation diffusion in relation to an Scurved timeline that illustrates the rate of diffusion across adopters (figure 1). The process of widespread adoption is plotted against time, and the individual's decision-making process that leads to acceptance or rejection of an innovation occurs on a timeline as well. This decision-innovation timeline is broken down into five steps: knowledge, persuasion, decision, implementation, and confirmation. First, in the knowledge stage, an individual encounters the innovation and gains an understanding of the job and function. Second, in the persuasion stage, an individual forms an opinion about the innovation, often after exposure to it through some media channel. Third, the individual decides to adopt or reject the innovation. The individual can reverse this decision at any point if dissatisfied with the adoption or if they decide the adoption is valuable. Fourth, the individual uses the innovation, and finally, the individual seeks external feedback about the innovation to reinforce or change their decision. 
Figure 1. Diffusion of an innovation across the population of adopters as a function of time (AtKisson 2017, modified from Rogers 2003, 112).

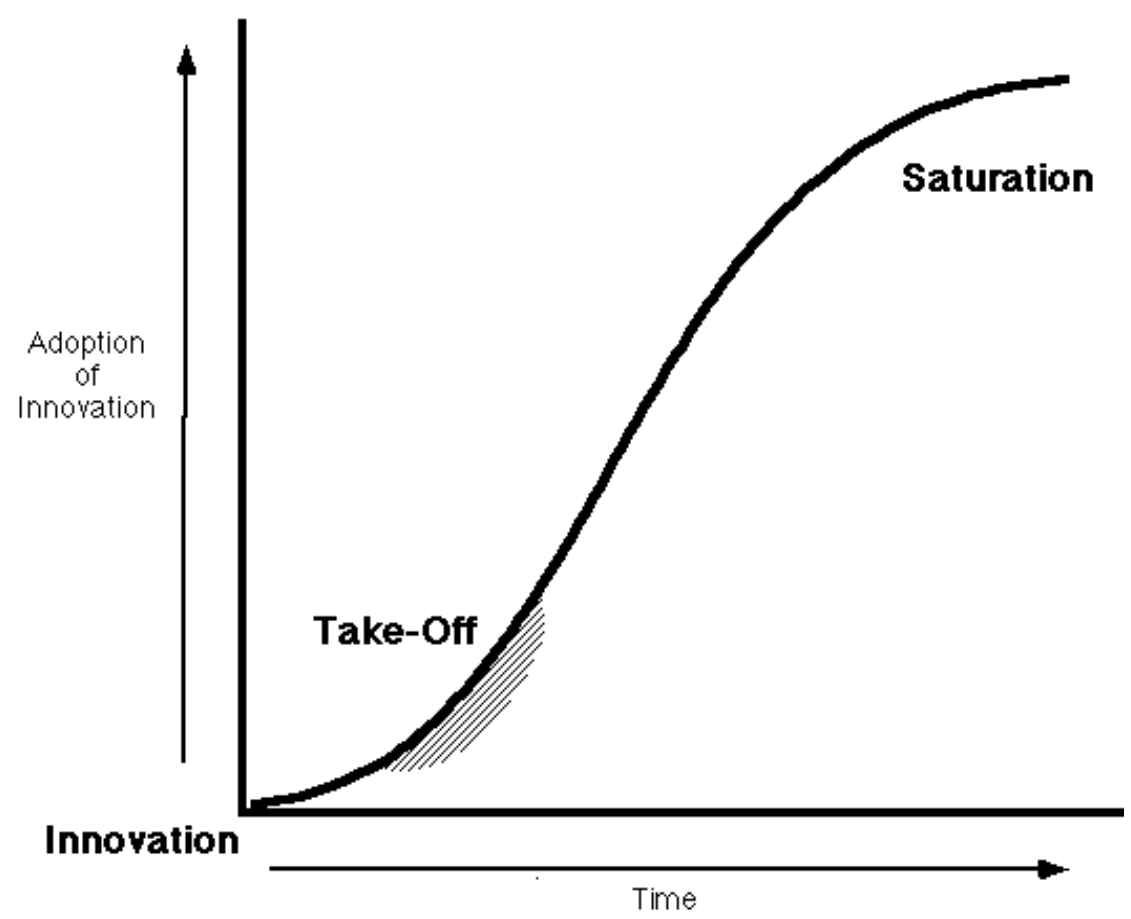

An important final concept of the theory is the social system, defined by Rogers as a series of interconnected units that link to achieve a common goal. As the theory explains, the units represent members of a social system that may be individuals, informal groups, organizations, or subsystems. Within the social system, both formal and informal structures exist. Formal structure "gives regularity and stability to human behavior in a system" through bureaucratic, hierarchical social structure, such as rank (Rogers 2003, 24). Informal structure exists within interpersonal networks that link a system's members or units; this structure is grounded in communication structures that are "tracing who interacts with whom under what circumstances” (Rogers 2003, 24). The social system's structure affects the diffusion and adoption of innovations, both by the nature of the social system and the individual's characteristics (Rogers 2003).

The five phases of innovation adoption are described in an S-shaped curve, illustrating the slow rate at which innovation adoption begins, the tipping point at which the rate accelerates, and the slowing of the rate at the end of the innovation process. In the first phase, innovators are the first to embrace a new technology. They are often able to accommodate high levels of uncertainty and have large interpersonal networks with which they can 
share the benefits of their adoption. Early adopters are similar in that, while they are not likely to base their decision to adopt the innovation on communication with others in their social system, their large networks enable them to share their adoption effectively. Together, Rogers asserts that innovators and early adopters make up 16\% of the innovation diffusion social system.

Figure 2. Adoption categorization on the basis of innovativeness (Rogers 2003, 171).

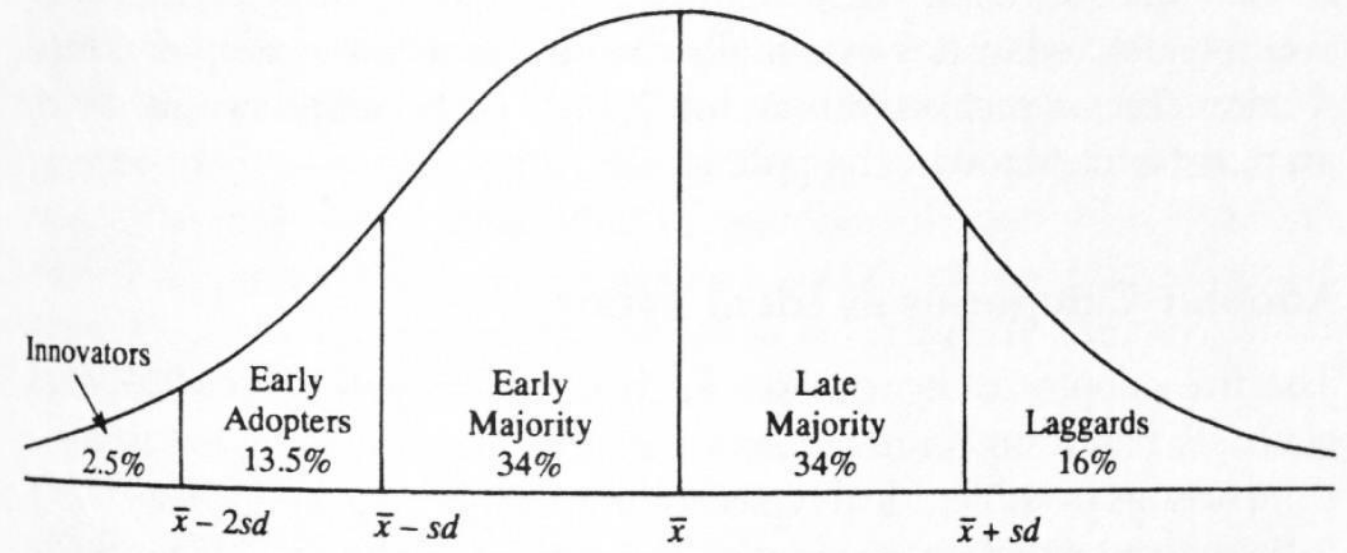

The early majority and late majority-each comprising $34 \%$ of the social system-are not making the decision to adopt on the basis of empirical evidence about the innovation's potential benefits, but on the basis of feedback on expected utility from others within their social network (figure 2) (Lovejoy et al. 2009). Barriers facing the two majority groups are likely to be those holding a new innovation back from being widely exposed to a network, or those preventing positive information about a new innovation from disseminating. Finally, the laggards, who account for the remaining $16 \%$ of the social network and the plateau of the S-curve are forced to adopt the innovation they resisted to remain competitive with others (Lovejoy et al. 2009, Rogers 2003).

Lovejoy et al. (2009) provide an effective example of innovation diffusion theory applied in practice. The researchers assessed the acceleration of online therapy adoption as a case study on innovation diffusion theory, using concepts from the theory as a guideline. First, the researchers identified nine barriers to innovation (Lovejoy et al. 2009). In line with Rogers's (2003) assertion that compatibility and relative advantage are the two most important components of innovation diffusion, four of the nine barriers in this case study involved compatibility issues, and two of the nine barriers involved relative advantage issues, for a total of two-thirds of the 
barriers. While there were other barriers resulting from complexity, trialability, and observability, overcoming the compatibility and relative advantage barriers proved paramount to the adoption of online therapy. Then, the authors made general recommendations, followed by recommendations made with each of the five criteria for innovation in mind.

Generally, the authors recommend targeting those likely to be early adopters instead of targeting those likely to be laggards. Using mass media as a source of knowledge about the new method and its implementation is a potential way to effectively target those early adopters. Another potential method to target early adopters is the presentation of empirical evidence in support of new online therapy systems.

In addition to studying the S-curve, innovation diffusion theory maps the rate of adoption by a "knowledge, attitude, and practice" process (Rogers 2003, 176). First, knowledge of the innovation precedes the development of an attitude about the innovation. Next, the development of an attitude includes persuasion, decision, and trial subcomponents of adoption. Finally, practice occurs when an individual has adopted the innovation and continues to use it. Characteristics of the innovation, organization, and individual also dictate the rate of adoption-particularly when considering issues such as cost of implementation, interconnectedness of social networks, and characteristics of the community.

\subsection{Examples of technology transition and adoption}

We undertook a general review of academic literature related to innovation research in general and the effectiveness of innovation adoption measures in the federal government specifically. We analyzed structural factors as they relate to an organization and its business processes and perceptual factors as they relate to an organization's personnel, customers, and stakeholders. We hoped to align these measures with interviewee responses and apply them to USACE and its navigation program. We also reviewed Government Accountability Office (GAO) reports detailing the efficacy of strategies and initiatives to improve program success and innovation within the federal government. The GAO reports provided more examples of barriers facing innovators and early adopters in other government contexts, which we hypothesized would identify potential limitations or caveats for technology diffusion strategies suggested by interviewees or the academic literature. 


\subsubsection{Sample Innovation Diffusion studies}

Taylor et al. (2003) explore knowledge transfer as a potential barrier to innovation, concluding that knowledge transfer played a key role in improving the existing technologies. Early- and late-majority adopters typically require a well-accepted technology to exist before adopting, whereas innovators and early adopters are more willing to take risks. Consequently, if knowledge transfer increases the likelihood of technological improvement, then the pace of information dissemination controls the rate by which adoption occurs in the majority groups. Once enough innovators and early adopters verify a technology's benefits and address its limitations, working units should broadcast technologies widely to maximize the rate and probability of adoption by the population.

Hubbard and Hayashi (2003) studied the diffusion of treatment improvement protocols in substance abuse rehabilitation and analyzed how to improve the dissemination of best practices. They identified and evaluated different methods of diffusion, and they asserted that a set of features suggested diffusion success at each step in the innovation diffusion theory's "knowledge, attitude, practice" process (Rogers 2003, 176). To move from increasing knowledge about an innovation to forming an attitude about it, adopters consider intrinsic properties of the innovation-such as the potential user base, its social networks, and how innovative the new technology is. To then move from the trial of the innovation to more consistent practice, perceived properties of the innovation-such as its relative advantage, reliability, and observability-become more important.

When evaluating the factors affecting state policymaking, Daley and Garand (2005) identified a series of influences that increased the likelihood of policy adoption in the context of abandoned or uncontrolled hazardous waste sites. States with more money were more likely to implement new policy programs, indicating that the cost of the program and availability of funding may be two major barriers to policy implementation. Daley and Garand also asserted that diffusion and dissemination across local entities, while not an indicator of innovation implementation alone, affect the creation or adoption of an innovation.

Koski (2010) identifies constraints on innovation diffusion for green building technologies that do not have strong public sentiment associated with them. The study identified low-salience policies developed by the US Green Building Council. These policies begin as small initiatives likely to 
be adopted by a small subset of early-adopting cities. The most pertinent factor to further adoption of these initiatives is a connection to public sentiment; if the policy cannot be disseminated in a way that emotionally involves the public, then increased backing for the idea will come to a halt. Slow, deliberate rollouts among larger and larger collections of working units (cities for green building standards, districts for USACE policies) provide opportunities to sample public sentiment on policies and iterate on or improve those policies before rolling out changes nationwide.

Wani and Ali (2015) used the framework of innovation diffusion theory to analyze the diffusion of smartphones, in particular throughout India. They argue that smartphones can be defined as innovations beyond the initial innovation of the mobile phone given their additional functionality over making mere phone calls. They also note that the theory of innovation diffusion has its origins in agriculture, not in industry, and thus there have been criticisms and concerns over the theory's applicability to other sectors. Still, they assert that innovation diffusion theory is useful for understanding the adoption by Indian consumers of smartphones.

Zanello et al. (2015) conducted a literature review of innovation diffusion theory as applied to private sectors in developing countries. They emphasize the importance of "account [ing] for the different innovation modes to isolate their diffusion patterns and their impact on firm performance" (5). They find that, for developing countries across different contexts and geographical areas, primary barriers to innovation as defined in the literature include poor education systems, political instability, unsecure legal systems, poor access to financial resources, cultural and linguistic distances, and inadequate infrastructure. Additionally, they note that knowledge diffusion to developing countries is predicated on the openness of the economy (26).

Collier et al. (2016) examine how best to approach risks which arise during the course of the technology innovation process. They note that often, such risks are handled through ad-hoc decision making, which often results in non-optimal decisions. To right this, they propose using Multi-Criteria Decision Analysis, a structured framework for making decisions grounded in preferences for different criteria, in concert with Mental Modeling and corporate social responsibility initiatives to make decisions throughout the technology innovation process. 
Becker et al. (2019) demonstrate the wide applicability of innovation diffusion theory by using it to examine the spread of radical ideas. In particular, they examine the spread of the ideas of Martin Luther, whom they deem an "ideological entrepreneur." They developed a network of Luther's early contacts based on letters he sent and towns which he visited and which published his works. Ultimately, they found that those towns where he had connections were much more likely to be early adopters of Reformation ideology than were other locales. This follows from Rogers's (2003) finding that opinion leaders tend to be cosmopolitan, communicating with diverse groups of people.

Zhang and Vorobeychik (2019) examine the growing popularity of agentbased modeling (ABM) of innovation diffusion, which is able to incorporate the heterogeneous nature of agents with fine-grained modeling. By examining modeling methodologies in the information field, they determine that the "maximum likelihood estimation framework" from this field could be a successful methodology for the calibration of agent-based models for innovation diffusion.

Klasa et al. (2020) examine how developed countries can participate in the innovations of -- or partner with -- emerging, or "newcomer," countries. They define such "newcomer" countries as "nations that are developing competency and breakthroughs in specific disciplines but have not yet attained global recognition for their expertise and capacity," explaining how partnering with such countries can be both beneficial but also risky. Their research highlights some of the challenges in creating and maintaining such partnerships, as well as how these challenges might be overcome, such as through various incentive programs.

International partnerships are also examined by Keisler et al. (2020). Like Klasa et al. (2020), they note that while established partnerships are safer, partnerships with newcomer nations can represent a "source of untapped benefits." Keisler et al. (2020) discuss modeling approaches and techniques that may be used to identify partners for innovation. They create an objective hierarchy to help guide decision makers, evaluating and comparing the various applicable methodological approaches. 


\subsubsection{Sample Innovation Diffusion in government}

We also assessed GAO reports in the literature review, because the reports serve as an independent, fact-based review of agencies' spending of taxpayer dollars. The GAO advises Congressional and executive agencies, such as USACE, on ways to make government "more efficient, effective, ethical, equitable, and responsive" (US Government Accountability Office). Thus, GAO reports serve as transparent and objective sources to garner information related to the success of government projects. We reviewed GAO reports from 2000-present that contained the word innovation and involved the agencies listed in appendix A, whose mission areas are complementary to those of USACE.

In total, we identified $58 \mathrm{GAO}$ reports, which we reduced to 37 after reviewing for duplication or relevancy to the current project. Common factors that led to inhibition or encouragement of innovation adoption were noted by the authors. These factors clustered naturally into nine categories, from most to least common: (1) collaboration and communication, (2) planning, (3) data collection, (4) hierarchy, (5) transparency, (6) defined goals, (7) cost estimate, (8) data analysis, and (9) staff education. All reports fell into one of these categories according to the factors influencing innovation, and any report could fall into multiple categories. See appendix B for category descriptions.

GAO has acknowledged the presence of barriers to innovation in USACE in the past. The GAO released a report in 2003 recommending that USACE begin collecting data to evaluate whether the USACE hopper dredge fleet was being appropriately employed (US Government Accountability Office 2003). The report also suggested that USACE evaluate the costs and benefits of the restrictions placed on the USACE hopper dredge fleet, to optimize the fleet's use (US Government Accountability Office 2003). Then, a follow-up 2005 report from USACE sought to improve the fleet's operations by exploring the dredging environment and its issues in order to recommend an optimal fleet schedule (US Army Corps of Engineers 2005). Environmental constraints and regulations restricted the fleet schedule and required the increase of private contractors when maintaining federal waterways. Further, limited access to hopper dredges as the result of minimizing fleet size affected timeliness and cost. Additionally, the fewer the contractors bidding on a job, the higher the cost. Ultimately, the 2003 GAO report provided a schedule for the USACE hopper dredges that GAO 
anticipated would reduce cost and enable the fleet to better meet peak demand. A 2014 report also set out to evaluate whether USACE had met the goals in the 2003 report (US GAO 2014). Specifically, the 2014 report evaluated the effects of restrictions on the hopper fleet and identified the challenges USACE faced in managing its hopper dredges (US GAO 2014). The report found that restrictions in the form of environmental windows and other environmental constraints had forced USACE to incur additional costs for owning and operating its hopper dredge fleet, regardless of the frequency of use (US GAO 2014). Further, having an increasingly limited time to operate meant that fewer private contractors had the resources to bid, causing the increase in cost (US GAO 2014). The presence of these barriers in both the 2005 USACE report and the 2014 GAO report necessitate the evaluation of how the USACE programs can overcome these barriers to better implement innovations.

\subsubsection{Collaboration, communication and planning, and data collection}

Figure 3 shows category frequency across the 37 reports. Collaboration and communication occurred as a factor in the adoption of an innovation the most. Over half of identified GAO reports discussed how a lack of communication or poor collaboration led to the failure of an innovation, while others described how successful communication benefited the development of an innovation. Planning also factored into many reports. Of those, 12 described cases of poor planning, and an additional 4 attributed a portion of the project's success to effective planning. In the case of projects whose goal is to transfer technologies and practices to the field for dredging operations, success is usually defined by whether that technology is adopted by the intended user base. Finally, only one report claimed data collection was the source of project's success, while twelve reports referenced inconsistent or undeveloped data collection methods. Data (for example, cost estimates) provide a foundational understanding of problems, which yields insight as to how and where new tools and technologies can be developed.

\subsubsection{Hierarchy, defined goals, and cost estimates}

Some reports mentioned hierarchy, with six reports mentioning how a lack of hierarchy had impeded progress and three illustrating successes due to a well-ordered organizational structure. Good organizational structure facilitated clearer communication between parties and more effective decision-making. A few reports mentioned defined goals, and most of these 
mentions highlighted how a project's lack of focused goals impeded project and innovation progress, while only one mentioned defined goals as a positive factor that helped project success. Cost estimates were rarely cited across the 37 reports as a hindering factor to a project, and accurate cost estimate predictions were cited twice as contributing to the success of a project.

Figure 3. Number of reports that mention factors contributing to adoption of innovation. Number reported reflects the count of reports across 37 total reports that mention each factor. Counts are inclusive if the report mentions more than one factor.

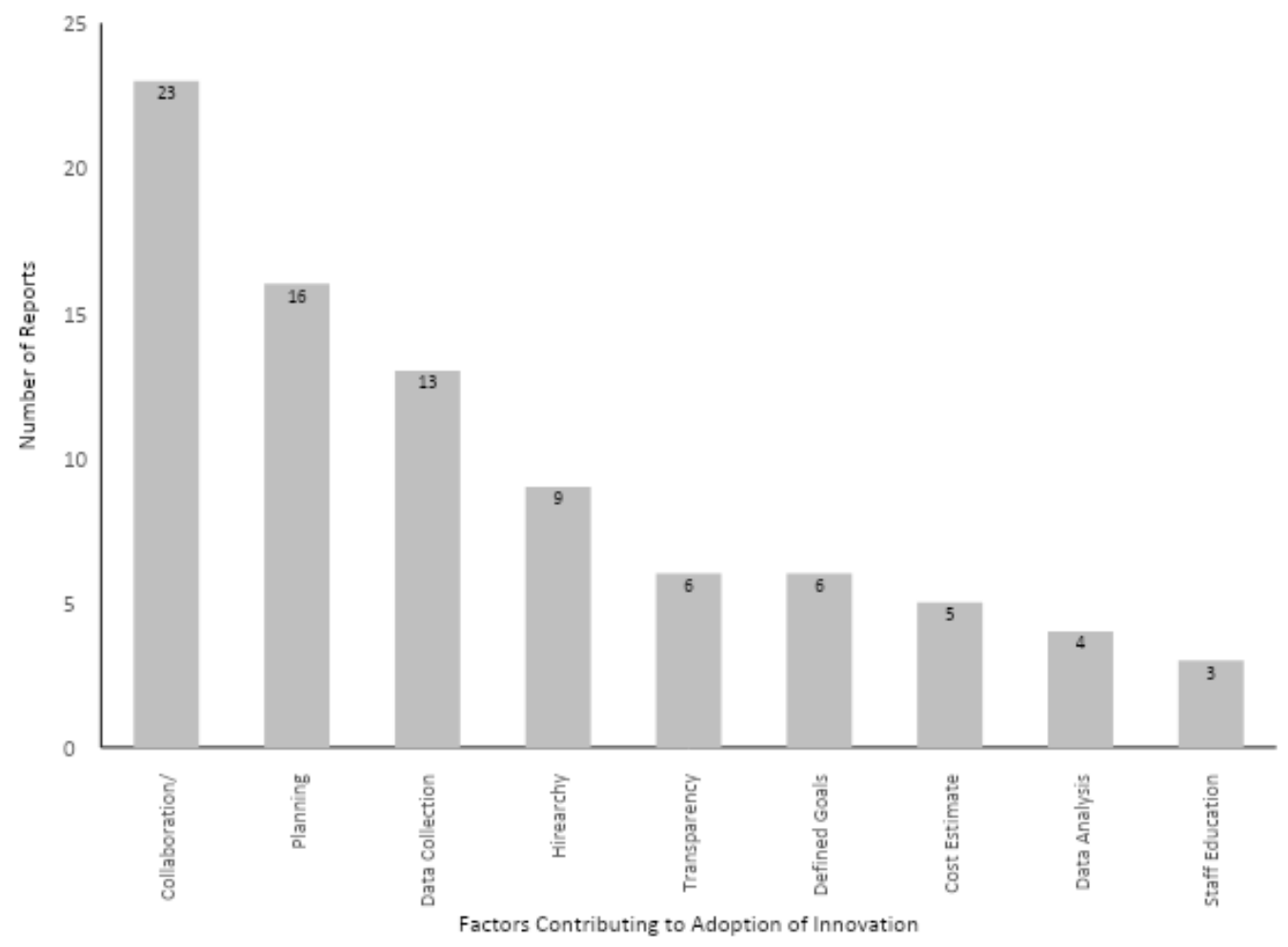

1.5.2.3 Transparency, data analysis, and staff education

Other topics referenced in identified GAO reports included transparency, data analysis, staff education, and data collection. Two reports cited transparency as a factor leading to a project's success, and four others cited it as a factor leading to project delays. While transparency itself might not be crucial to a project's success, it is often essential for gaining the support of other departments, agencies, and the public. A few reports mentioned data analysis, each pointing to a failure to properly analyze available data. One report illustrates that while data analysis is helpful, determining effective questions when analyzing the data is just as important as the analysis itself (US GAO 2015). Three separate reports acknowledged staff education as a 
significant cause of a project's failure. The wide range of skills needed in prospective staff can be difficult to find, and staff must continue to learn new skills throughout their employment. Even when qualified candidates are found, hiring freezes and retirements can make it difficult to maintain appropriate staff skill levels. 


\section{Mental Modeling Research Exercise}

\subsection{Method}

In order to understand opportunities and barriers for dredging innovations across USACE and its partners, we conducted mental model interviews (Morgan et al. 2002). Expert modeling is a well-accepted method for formulating problems, developing an understanding of variations in expertise, and analyzing that expertise as a function of the amount or different types available for a policy or engineering challenge (Jones et al. 2011; Bridges et al. 2013; Gray et al. 2014; Halbrendt et al. 2014; Wood et al. 2017). Expert modeling was initially developed to expedite the creation of risk communication plans, under the assumption that laypersons could reach expert understanding on a risk issue if the deficits in layperson knowledge could be identified in terms of expert understanding (Woods et al. 2017). Written communications then help laypeople to improve from their current (limited) knowledge of a problem through simple analogies that communicate risk processes in terms of well-understood everyday phenomena (Morgan et al. 2002). Past projects involved generalist knowledge on climate change, flashfloods, and landslides (Lowe et al. 2007; Read et al. 1994; Bostrom et al. 1994; Wager 2007) and public views on carbon-sequestration approaches (Palmgren et al 2004). A key part in the process is the development of the expert model (EM), a representation of key variables in a system and how they interact with one another in the decision context. The influence diagram-the visual account of these key variables-shows the strength of each variable's influence on the other variables in the system and the direction in which that influence is aimed. In this case, the project team first developed a draft EM with a small number of USACE experts. The team then elaborated this draft model into an EM and series of submodels illustrating emphasis of each cohort on different components of the EM (Wood, Kovacs, et al. 2012). We developed the protocol to understand variations in perspective among those within USACE and those within other stakeholder groups that interact with the USACE Navigation Program (Wood, Kovacs, et al. 2012).

This process started with draft and simple mental models that we then developed through a review of the academic literature and federal reports on technology development applicable to navigation and sponsor feedback in order to generate a structured interview protocol. This structured interview first asks interviewees to speak broadly about topics of interest then 
drills down into specifics of those topics when interviewees fail to mention specific items endogenously. An influence diagram illustrates common themes, where nodes denote concepts and arrows denote the direction of their influence. We selected Navigation Operations and Maintenance (herein Nav O\&M) because it represents a substantial portion of the navigation program's portfolio, occurs at scheduled periods for most navigation projects, and presents an opportunity within the USACE for the current rate of technological innovation to improve.

A sample of individuals $(\mathrm{N}=25)$ familiar with USACE Navigation Program dredging operations participated in structured interviews for the project team to better understand specifics related to the concerns and opportunities for innovation diffusion in this context. Participants represented USACE employees across the organization as well as other federal agencies, nonprofit organizations, and contractors.

\subsubsection{Influence diagram development}

We conducted unstructured interviews with eight USACE personnel representing navigation managers, researchers, and other knowledgeable staff to understand key issues in the current process of the USACE Navigation Program's design and execution processes. Participants in unstructured interviews answered questions about the current state of Nav O\&M, dredging operations, and innovation in USACE to gain a preliminary understanding about the current state of problems and opportunities. We then developed the simple mental model (figure 4) to codify key issues and develop a rough guide for these interviews.

We then conducted a review of the literature to investigate further the concepts identified in these interviews, specifically focusing on academic studies pertaining to innovation diffusion and related problems as well as how the federal sector identified and addressed diffusion problems (see section 2). We reviewed USACE professional development course materials to provide background information on USACE dredging processes (54DFMo1A Dredging Fundamentals PROSPECT Course, 2011) as well as USACE Dredging Operations and Technical Support Program webinars (https://dots.el.erdc.dren.mil/resources.html) and dredging manuals (USACE 1983, 1987bc, 1996; USEPA and USACE, 2007, USACE 2015). 
Figure 4. Simple mental model of Navigation O\&M Program innovation.

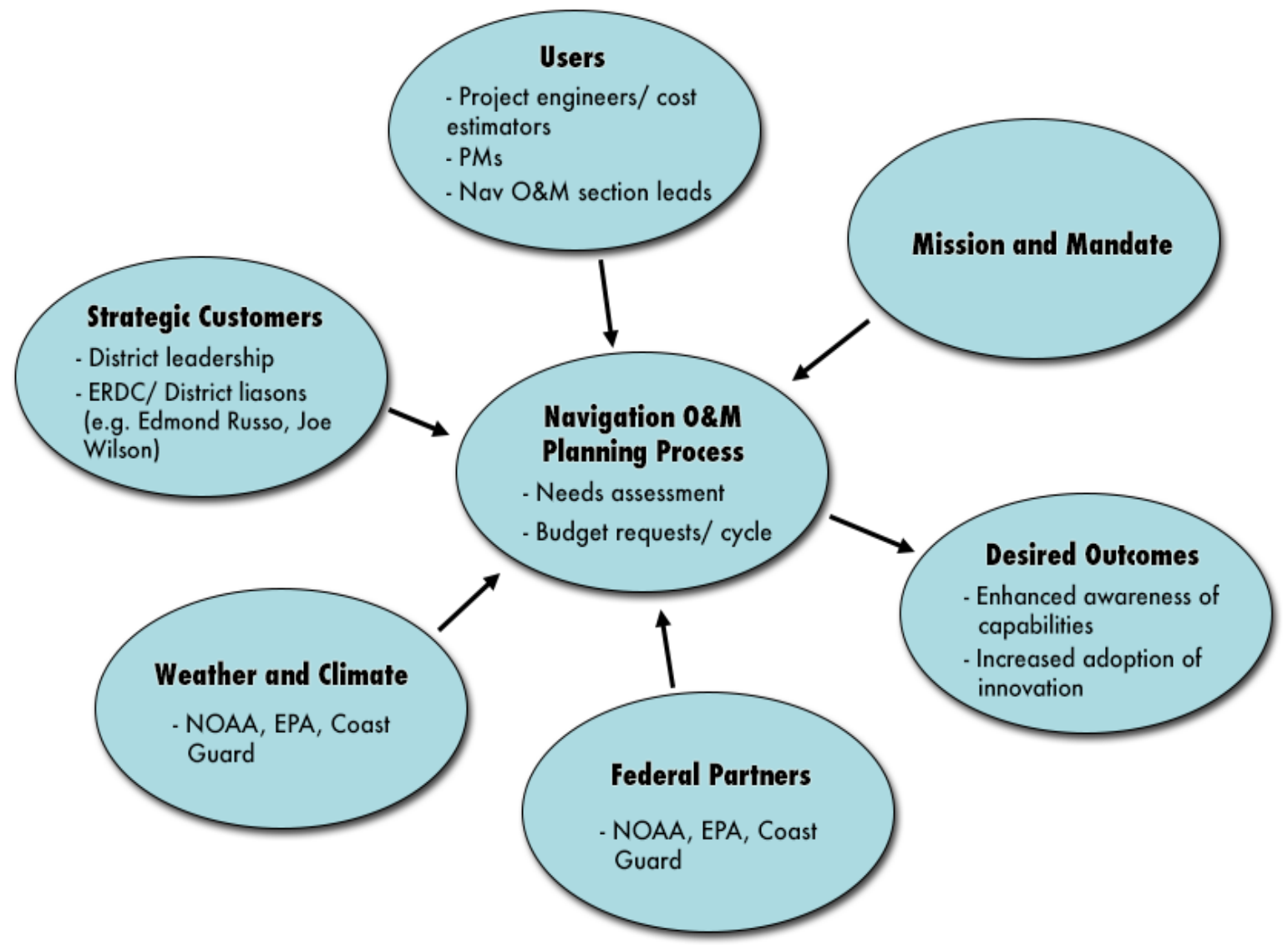

Figure 4 was used to develop an influence diagram representation of important factors in Navigation O\&M and the relationships between these factors. The resulting Draft Mental Model of Navigation O\&M Innovation (Figure 5), is an initial representation of the way that knowledgeable Navigation practitioners think about and perceive various elements of the Navigation O\&M process and the mechanisms by which it might be improved. 
Figure 5. Draft expert mental model of cognitive barriers to innovation in Navigation Operations and Maintenance (Nav O\&M).

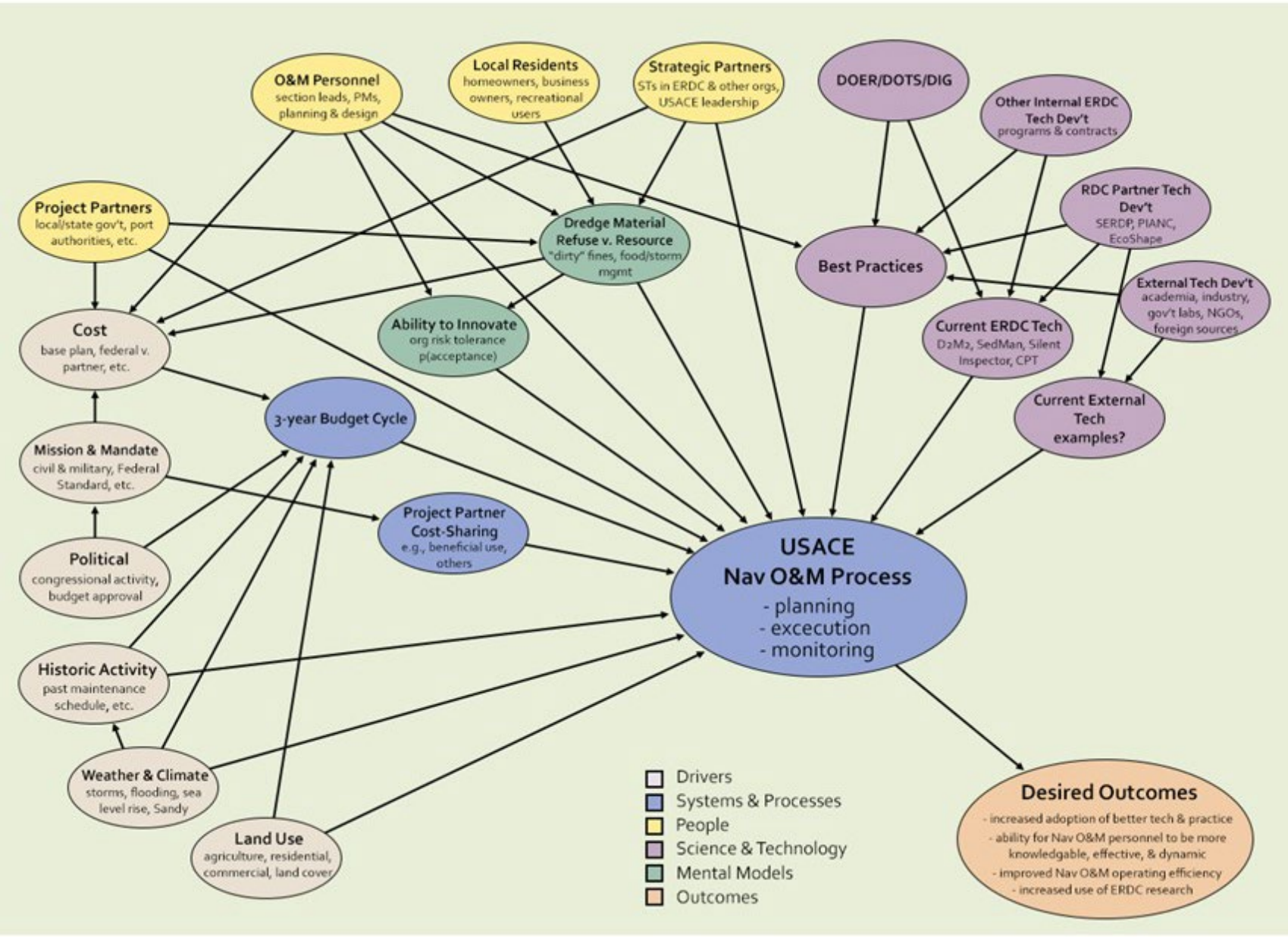

\subsubsection{Interview protocol development}

We used the draft mental model (figure 5) to develop a structured mental models interview protocol (appendix C) for asking a variety of subject matter experts about the current barriers and opportunities for innovation diffusion in the Nav O\&M business line (figure 6 for summary). The interview starts by asking participants to briefly describe the current process USACE uses to plan and execute navigation efforts, followed by targeted questions about each phase of the process, and then questions about where either roadblocks or opportunities for innovation exist. We developed the protocol in part using feedback from DOER Program personnel. 
Figure 6. Summary of interview protocol.

Introduction

Purpose

Summary of topics

Definitions

Drivers

What are the most important factors that influence USACE's navigation activities?

Are these drivers internal or external to the organization?

People and Organizations

\subsubsection{Recruiting and interviews}

We used the snowball sampling approach (Goodman 1961), where candidate participants were identified through recommendations by DOER Program personnel and responses from unstructured interviews (section 3.1.1.). This approach is useful for when candidates are hard-to-reach experts.

Interviewees were stratified across four cohorts according to the agency or organization they represent: USACE $(n=7)$; other government $(n=4)$; nongovernment organization (NGO, $n=5)$; and contractors $(n=7)$. These cohort sample sizes are consistent with those in the literature (Bridges et al. 2013; Wood, Kovacs, et al. 2012; Wood et al. 2017) and are intended to develop an understanding of the variety of points of view related to innovation in the navigation program rather than to provide a high-resolution quantitative measure of the degree or intensity of specific perceptions or beliefs. We used recommendations from unstructured interview participants and the project sponsor to identify potential interviewees to solicit. This resulted in a list of 39 potential participants, who were solicited via email, representing a return rate of $64 \%$. The goal of this recruitment and stratification strategy was to provide a robust, holistic view of the current state of navigation as well as highlight potential opportunities for improvement. See table 1 below for a list of represented organizations. Two of the contractor interviews were conducted with pairs of individuals who represented the organization, so while seven individuals participated, they did 
so in five interviews. Two individuals representing the US Fish and Wildlife Service participated to cover that agency's perspectives with respect to both coastal and inland navigation.

Table 1. List of organizations represented in interviews.

\begin{tabular}{|ll|}
\hline & Buffalo District (NY) \\
& Chicago District (IL) \\
& Huntington District (WV) \\
& Huntsville Engineering \& Support Center \\
& Mobile District (AL) \\
& New England District \\
& Portland District (OR) \\
& \\
\hline \multirow{3}{*}{ Other Government Agencies: } & Duluth Seaway Port Authority \\
& US Fish \& Wildlife Service \\
& \\
\hline NGOs: & American Shore \& Beach Preservation \\
& Association \\
& Inland Rivers, Ports, and Terminals \\
& lowa Corn Growers Association \\
& Western Dredging Association \\
& \\
\hline Contractors: & Association of General Contractors \\
& Dredging Contractors of America \\
Great Lakes Dredge \& Dock & Manson Construction \\
Moffatt \& Nichol \\
Norfolk Dredging Company \\
Piedroba Consulting \\
\\
\hline
\end{tabular}




\section{Results}

The project team transcribed by hand the recordings of the interviews and evaluated their content. A member of the team with experience in system design and qualitative analyses created an initial EM using informal testimonies from industry experts. We applied qualitative data analysis, using draft EM node concepts as coding labels, to passages of the transcriptions with thematic commonalities to allow for comparison across interviews of concepts represented in the EM with a two-pass process using the R Statistics package RQDA (Huang, 2016). In the first pass, codes were applied to transcripts, making annotations where either code definitions should be changed or expanded or new codes (and associated model nodes and influences) should be developed. After the first pass, nodes were updated to reflect annotated refinements (see appendix D for final version), and a second pass of transcripts was performed to ensure that changes to codes were applied uniformly across the dataset. The final expert model included 47 unique nodes, compared to 23 for the draft expert model (figure 3).

\subsection{Influence diagrams}

Figure 5 illustrates the final expert model for all interviewees. It represents the current state of the USACE Navigation Program and provides a tool for qualitative review of how changes to one or more nodes in the system (for example, through innovation) may percolate through the system to change the final outcomes node. Nodes are colored according to the category to which they belong; for example, all orange nodes are members of the parent category Nav O\&M drivers. Node color saturation is based on the frequency with which a code is referenced: full saturation means the code appeared in every interview, while no saturation (white) means the code was absent. We updated this final model using the draft expert model to reflect influence relationships described in the interviews, and we combined or removed concept nodes depending on their frequency.

Nav O\&M drivers (orange nodes) in the lower left corner are likely to influence concepts like weather and historical precedents in dredging, while current political considerations affect all navigation needs and the extent to which contractors are able to fulfill those needs. Similarly, constraints in funding and resources also affect how USACE fulfills the navigation mission, and their impact on the bidding process is shown in the influence diagram. Within the node category itself, the most important influence is 
that of political factors on the USACE mission and mandate; current Congressional activity or budgetary constraints affect the ability of USACE to meet the conditions set out in its mission. All of these factors impact the ability for USACE and partners to deploy new technologies and methods during the dredging process in the service of the overall navigation mission, or provide challenges and constraints that a change in business practice or technology may overcome.

People (yellow nodes) are in the top left corner of the influence diagram and include USACE employees, leaders, and partners, who all influence the expected cost of a given project. These employees are the ones who will dictate the scope of a particular dredging project, and these decisions will influence the anticipated cost of the project as well as any further cost restraints imposed on USACE as a whole. Within the node category, the most notable are those that affect USACE HQ and leadership. Local residents and external stakeholders both influence USACE HQ and leadership, suggesting that groups outside of USACE are able to impact USACE Nav O\&M processes.

Mental models (green nodes) tend to influence technology development and organizational research, as shown by their connections with science and technology nodes. Mental models nodes signify the need, importance, or dearth of innovation in a variety of contexts. The science and technology nodes often influence the best practices node; newly implemented technologies shape ideal best practices for specific problem classes.

The USACE Nav O\&M process node is the final variable in the influence diagram. All other nodes influence it or the other nodes adjacent to it (such as best practices, bidding process), since all of the people, drivers, technologies, and constraints are ultimately affecting the USACE Nav O\&M process. This node then leads to one last node: outcomes. All preceding nodes, naturally, influence the outcomes node, and changes in outcomes result from changes in the preceding variables, or connections between then that new technologies or practices introduce.

\subsection{Cohort analysis}

We constructed five influence diagrams for different subsets of interviewees. The final expert model represents data from all interviews, with four submodels representing results for each interview cohort: USACE, other government, NGOs, and contractors. 
Figure 7. Final expert mental model of navigation.

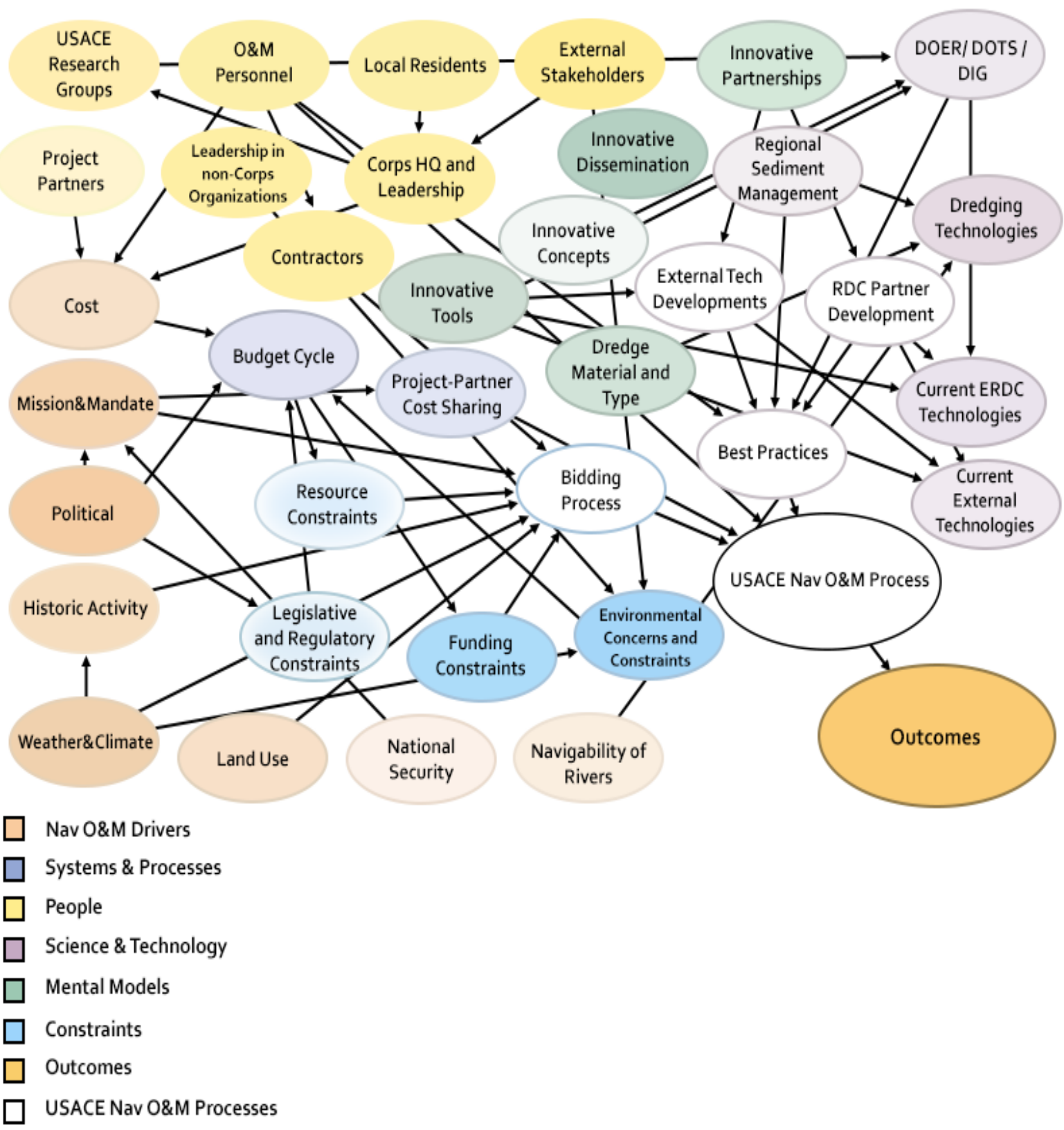

Figure 7 represents the influence diagram of relationships when evaluating all 23 interviews. For example, the political and external stakeholders node categories were mentioned most frequently, and the nodes environmental concerns and constraints, USACE HQ and leadership, and leadership in non-USACE organizations was mentioned the second most frequently. Ultimately, this suggests that stakeholders, both inside and outside of USACE, have the most influence in navigation operations. 
However, external stakeholders and USACE HQ and leaderships' decisionmaking may be most influenced by political and environmental issues. For instance, when asked about key external drivers that influence Nav O\&M and USACE, one interviewee claimed that "of course, the most significant one is probably from outside the Corps in the environmental windows," a sentiment shared by many interviewees. Another interviewee shared this belief and suggested that "a more collaborative approach to the environmental issues and opportunities that the dredge material and the maintenance of these navigation channels provides to help achieve what these stakeholder centric goals and objectives are for their ecosystem."

Interviewees suggested that external regulations are restrictive, which may be accentuated by the inflexible collaboration between USACE teams and regulatory and environmental agencies. One interviewee remarked that "everybody just kind of sits in what they can and can't do".

Table 2. Highest-weighted codes from each interviewee group and their weights.

\begin{tabular}{|c|c|c|c|c|c|c|}
\hline Node Category & Node & $\begin{array}{l}\text { All } \\
\text { Interviewees }\end{array}$ & Contractors & NGOs & $\begin{array}{l}\text { Other } \\
\text { Government } \\
\text { Employees }\end{array}$ & $\begin{array}{l}\text { USACE } \\
\text { Employees }\end{array}$ \\
\hline \multirow{5}{*}{$\begin{array}{l}\text { Nav O\&M } \\
\text { Drivers }\end{array}$} & Political & 0.96 & 1 & 1 & & 1 \\
\hline & $\begin{array}{l}\text { Mission \& } \\
\text { Mandate }\end{array}$ & & 0.86 & & & 0.875 \\
\hline & Historic Activity & & & & 1 & \\
\hline & $\begin{array}{l}\text { Weather \& } \\
\text { Climate }\end{array}$ & & & 1 & 1 & \\
\hline & Land Use & & & & 1 & \\
\hline \multirow[t]{7}{*}{ People } & $\begin{array}{l}\text { External } \\
\text { Stakeholders }\end{array}$ & 0.96 & 1 & 1 & 1 & 0.875 \\
\hline & $\begin{array}{l}\text { Corps HQ and } \\
\text { Leadership }\end{array}$ & 0.83 & 0.86 & & 1 & 0.875 \\
\hline & $\begin{array}{l}\text { Leadership in } \\
\text { non-Corps } \\
\text { Organizations }\end{array}$ & 0.83 & 0.86 & & 1 & 0.875 \\
\hline & Contractors & & 0.86 & & & \\
\hline & Q\&M Personnel & & & 1 & 1 & \\
\hline & $\begin{array}{l}\text { USACE } \\
\text { Research } \\
\text { Groups }\end{array}$ & & & & 1 & \\
\hline & Local Residents & & & & 1 & \\
\hline Mental Models & $\begin{array}{l}\text { Innovative } \\
\text { Dissemination }\end{array}$ & & & 1 & & \\
\hline \multirow[t]{2}{*}{ Constraints } & $\begin{array}{l}\text { Environmental } \\
\text { Concerns and } \\
\text { Constraints }\end{array}$ & 0.83 & 0.86 & 1 & 1 & \\
\hline & $\begin{array}{l}\text { Funding } \\
\text { Constraints }\end{array}$ & & & & & 0.875 \\
\hline
\end{tabular}


Among cohorts, some nodes appeared consistently on the most highly weighted lists. External stakeholders, for example, was one of the most frequently used nodes when evaluating any of the unique cohorts. One interviewee claimed that "sometimes [external stakeholders] can swing the whole gamut," elaborating that they could "prevent you from innovating because they just make trying to do something different so painful." Another NGO-affiliated interviewee had a less bleak view on their influence, claiming "they're generally helpful in providing suggestions" while also acknowledging the difficulty in appeasing diverse groups of stakeholders.

Other nodes-political, environmental concerns and constraints, USACE HQ and Leadership, and Leadership in non-USACE Organizations-were often mentioned in all cohorts. The former two nodes were both used to suggest cost constraints on USACE's ability to innovate; one interviewee insisted "the politics drives things, and it's based on funding, [and] there's not enough money in the government pot to do it." Similarly, many interviewees spoke about the environmental windows that contractors must often adhere to. Environmental windows - the periods of time during which dredging is allowed-were mandated with the passage of the National Environmental Policy Act (1969) to protect endangered or migrating species that could be killed during the dredging process (Reine, Dickerson, and Clarke 1998; TRB 2002). One interviewee claimed that environmental considerations factored too heavily into navigation program decisions: "it really burdens contractors] because the cost to mitigate environmental concerns is unnecessarily high for the results that it achieves." The frequency of these nodes, and the associated line of argument codified with them, indicates the significance of costs on the dredging innovation process.

The node USACE HQ and leadership and leadership in non-USACE organizations both hinted at similar themes: leadership decisions and initiatives are ineffective if the staff and money required to introduce them are not available. One NGO-affiliated interviewee thought that "senior [Corps] leaders are overburdened," while another said that USACE leadership is "limited in what they can do," suggesting that USACE staff may be too overworked to focus on innovating and instead addressing only the most immediate problems and needs. In addition to a claim that USACE staff are also restricted by inadequate funding, interviewees speaking about 
leadership in non-USACE organizations asserted that there needs to be cooperation among USACE and non-USACE leaders to meet their common goal.

When analyzing nodes that appeared most frequently in only one or two of the four cohorts, there are often connections between the cohort and the nodes they individually highlighted. For example, contractors appeared most frequently only when assessing the group of contractors who were interviewed. One interviewed contractor asserted that, though contractors could have an impactful relationship with USACE and its dredging processes, they are unable. The idea that contractors could be-and were willing to-help improve USACE navigation and dredging processes was an oft-repeated one. One contractor suggested that getting contractors involved earlier in projects could "optimize specific approaches for each specific project," with three of the other contractors interviewed agreeing. One interviewee suggested that USACE would benefit from more general flexibility in allowing external influence from contractors. Across the interviewed contractors, the notion that the navigation program should engage more with contractors as a way to increase contracting bids and innovation recurred.

The funding constraints node was only heavily weighted when evaluating interviews from USACE employees. Those with a familiarity of the budget process might be more cognizant of the ways cost and constraints on cost affect the USACE navigation process and are thus more likely to mention those constraints. The nodes weighted most highly in the group of other government employees often also varied most greatly from the nodes in the other groups. Frequent mentions of land use, local residents, and USACE research groups only appear in this cohort of other government employees. The small size of the cohort created larger changes in weights for each participant who mentions a concept relative to the other cohorts; to see whether or not the values of other government employees resemble those of the other cohorts, a larger sample of interviewees is necessary.

\subsection{Co-occurrence analysis}

We weighted arrows connecting nodes using the proportion of interviews that references both nodes. If two nodes were both present in the same interview, that pairing received a one, and if not, each node received a zero. Then, we summed the score for that pairing across all interviews, or across all interviews belonging to a cohort, and assigned score for that influence. 
Higher weights suggest that the two nodes were mentioned together more often and, therefore, that interviewees agree this connection has an important influence in Nav O\&M.

Table 3 shows the highest weighted influences in each of the four interviewee cohorts. Some appeared frequently in most of the cohorts: appearing in all cohorts were external stakeholders influencing USACE HQ and leadership, external stakeholders influencing environmental concerns and constraints, and leadership in non-USACE organizations influencing environmental concerns and constraints. All three of those nodes appeared frequently when evaluating all cohorts on the basis of weighting nodes alone, so their frequent appearance when evaluating connected nodes is unsurprising. In relation to the influence diagram, these results suggest that external stakeholders are the most frequent influence behind the actions and behaviors of those in USACE, and that the decisions made by members of USACE and stakeholders outside USACE often go on to affect the environmental windows.

Many of the nodes are influenced by or influencing nodes within the same node category. A more complicated set of node connections-in which nodes from a larger variety of node categories are valued by similar interviewees-suggests complexity (Wood et al. 2017; Morgan et al. 2002). A problem that involves equal input from all groups represented by node categories would require a more resource-intensive solution. However, because the problem seems to be localized to a few node categories, it may be a simpler problem than anticipated. This appearance, however, does not mean that the solution is an easy one in reality; the problem facing USACE is simple in the number of involved parties, yet challenging in its execution.

These results also suggest that a large group of nodes-primarily in node categories such as systems and processes, science and technology, and mental models-are ignored by enough interviewees to make them irrelevant when examining nodes by frequency of mention. Inherently interdisciplinary problems, such as the one currently facing USACE, are best solved if individuals with combining skill sets and problem representations work together (Linkov et al. 2014). We recommend that USACE seeks solutions covering a larger range of topics than those that interviewees focused on. 
Table 3. Most highly weighted arrows in all interviewee groups.

\begin{tabular}{|c|c|c|c|c|c|c|}
\hline $\begin{array}{l}\text { Node } \\
\text { Category } \\
\text { Connectors }\end{array}$ & Connectors & $\begin{array}{l}\text { All } \\
\text { Interviewees }\end{array}$ & $\begin{array}{l}\text { Contract } \\
\text { ors }\end{array}$ & NGOs & $\begin{array}{l}\text { Other } \\
\text { Gov't } \\
\text { Employees }\end{array}$ & $\begin{array}{l}\text { USACE } \\
\text { Employees }\end{array}$ \\
\hline \multirow{2}{*}{$\begin{array}{l}\text { Nav O\&M } \\
\text { Drivers } \rightarrow \\
\text { Nav O\&M } \\
\text { Drivers }\end{array}$} & $\begin{array}{l}\text { Political -> Mission \& } \\
\text { Mandate }\end{array}$ & 0.79167 & 0.8751 & 0.8 & 1 & 0.875 \\
\hline & $\begin{array}{l}\text { Weather \& Climate -> } \\
\text { Historic Activity }\end{array}$ & & & 0.8 & 1 & \\
\hline $\begin{array}{l}\text { Nav O\&M } \\
\text { Drivers -> } \\
\text { Constraints }\end{array}$ & $\begin{array}{l}\text { Weather \& Climate -> } \\
\text { Environmental Concerns } \\
\text { and Constraints }\end{array}$ & & 0.7143 & 1 & & \\
\hline \multirow{2}{*}{$\begin{array}{l}\text { People -> } \\
\text { Nav O\&M } \\
\text { Drivers }\end{array}$} & $\begin{array}{l}\text { Corps HQ \& Leadership - } \\
>\text { Cost }\end{array}$ & & & 0.8 & & \\
\hline & O\&M Personnel -> Cost & & & 0.8 & & \\
\hline \multirow[t]{4}{*}{$\begin{array}{l}\text { People -> } \\
\text { People }\end{array}$} & $\begin{array}{l}\text { External Stakeholders -> } \\
\text { Corps HQ \& Leadership }\end{array}$ & 0.875 & 0.8571 & 0.8 & 1 & 0.875 \\
\hline & $\begin{array}{l}\text { Corps HQ \& Leadership - } \\
\text { > USACE Research } \\
\text { Groups }\end{array}$ & & 0.7143 & & 1 & 0.75 \\
\hline & $\begin{array}{l}\text { O\&M Personnel -> } \\
\text { Contractors }\end{array}$ & & & 0.8 & & \\
\hline & $\begin{array}{l}\text { Local Residents -> Corps } \\
\text { HQ \& Leadership }\end{array}$ & & & & 1 & 0.75 \\
\hline \multirow[t]{2}{*}{$\begin{array}{l}\text { People -> } \\
\text { Constraints }\end{array}$} & $\begin{array}{l}\text { External Stakeholders -> } \\
\text { Environmental Concerns } \\
\text { and Constraints }\end{array}$ & 0.875 & 0.8751 & 1 & 1 & 0.75 \\
\hline & $\begin{array}{l}\text { Leadership in non-Corps } \\
\text { Organizations -> } \\
\text { Environmental Concerns } \\
\text { and Constraints }\end{array}$ & 0.79167 & 0.7143 & 0.8 & 1 & 0.75 \\
\hline
\end{tabular}


Table 4. Highly weighted arrows by frequency.

\begin{tabular}{|c|c|c|c|c|c|}
\hline Connectors & $\begin{array}{l}\text { All } \\
\text { Interviewe } \\
\text { es }\end{array}$ & $\begin{array}{l}\text { Contractors } \\
\left(“ A^{\prime \prime}\right)\end{array}$ & $\begin{array}{l}\text { NGOs } \\
\text { (“B”) }\end{array}$ & $\begin{array}{l}\text { Other Gov't } \\
\text { Employees } \\
\left(“ \mathrm{C}^{\prime}\right)\end{array}$ & $\begin{array}{l}\text { USACE } \\
\text { Employees } \\
\text { (“D”) }\end{array}$ \\
\hline $\begin{array}{l}\text { External Stakeholders -> Corps } \\
\text { HQ \& Leadership }\end{array}$ & 0.875 & 0.8571 & 0.8 & 1 & 0.875 \\
\hline $\begin{array}{l}\text { External Stakeholders -> } \\
\text { Environmental Concerns and } \\
\text { Constraints }\end{array}$ & 0.875 & 0.8571 & 1 & 1 & 0.75 \\
\hline $\begin{array}{l}\text { Leadership in non-Corps } \\
\text { Organizations -> Environmental } \\
\text { Concerns and Constraints }\end{array}$ & 0.79167 & 0.7143 & 0.8 & 1 & 0.75 \\
\hline Political -> Mission \& Mandate & 0.79167 & 0.8571 & 0.8 & & 0.875 \\
\hline $\begin{array}{l}\text { Corps HQ \& Leadership -> } \\
\text { USACE Research Groups }\end{array}$ & & 0.7143 & & 1 & 0.75 \\
\hline $\begin{array}{l}\text { Weather \& Climate -> } \\
\text { Environmental Concerns and } \\
\text { Constraints }\end{array}$ & & 0.7143 & 1 & 1 & \\
\hline Corps HQ \& Leadership -> Cost & & & 0.8 & & \\
\hline Q\&M Personnel -> Contractors & & & 0.8 & & \\
\hline Q\&M Personnel -> Cost & & & 0.8 & & \\
\hline $\begin{array}{l}\text { Weather \& Climate -> Historic } \\
\text { Activity }\end{array}$ & & & 0.8 & 1 & \\
\hline $\begin{array}{l}\text { Local Residents -> Corps HQ \& } \\
\text { Leadership }\end{array}$ & & & & 1 & 0.75 \\
\hline
\end{tabular}




\section{Conclusion}

USACE and its partners are continually innovating and developing new dredging technologies, tools, and practices. A number of opportunities exist to improve the technology and innovation transfer potential of ERDC research to the USACE Navigation Program. Transition failures identified in this research are not attributed to the technology development cycle or navigation program business processes per se but rather are largely a result of perceptions of applicability and utility (or lack thereof) of those tools or poor communication between parties that need to work together in order to identify opportunities for technologies to succeed.

The final expert model, influence diagram, and co-occurrence analysis point to opportunities for improving the USACE Navigation Program through new practices and technologies, and identified barriers in dredging innovation adoption. Viewing these opportunities and barriers through Rogers's innovation diffusion theory (2003) and as practiced in studies highlighted in the literature review, we have identified several opportunities for improving innovation diffusion while acknowledging and anticipating potential barriers in technology transition.

Many interviewees recognized the research and development carried out by USACE in the knowledge phase, with one interviewee claiming, "ERDC is way ahead of the state...I can't say enough good things about ERDC." Yet, while dredging knowledge and technology are developed and available, the applicability and utility of the innovations can be better communicated-starting in the persuasion phase, in which innovators communicate the benefits of their innovations. While programs like Dredging Operations Technical Support help transfer technologies and best practices to districts in a formal way, the transition mechanisms available to districts through the navigation program or other sources to learn from federal environmental agencies or contractors are often ad hoc. USACE currently has no formal measure of technology transfer into its navigation program, although dredging cost per cubic yard or other indicators as a function of technology deployment could provide some indirect measures. Measuring the rate of technology diffusion and the benefits from doing so may help to draw more attention to a need to innovate at the district or navigation program level, and may help to incentivize change and productive competition across USACE work units to improve their effectiveness through 
innovation. Several opportunities also exist for sharing innovations across the organization.

\subsection{Communication channels}

On the basis of the interviews, we postulate that USACE could improve its communication channels both within USACE and with external stakeholders (contractors, regulatory and environmental agencies, and the public) to refine its position in the larger, more complex social system so that more of its innovations are adopted and implemented. For instance, one interviewee remarked that "the research and development programs related to navigation by and large are well connected. It's the ability to promote when the product is finished and ready to be rolled out that there seems to be a lack of funding and maybe even the wrong personnel skill set to really help communicate this new innovation and help with it being implemented."

Stakeholders both inside and outside of USACE influence one another. Specific to USACE, external stakeholders influence USACE HQ and leadership. Additionally, all stakeholders are impeded by environmental concerns and constraints. Across every cohort in table 4, interviewees mentioned the following pairs of concepts in their responses: external stakeholders influencing USACE HQ and leadership, external stakeholders influencing environmental concerns and constraints, and leadership in non-USACE organizations influencing environmental concerns and constraints. These relations suggest that external stakeholders and leaders in non-USACE organizations influence the environmental concerns and constraints. The external stakeholders who influence and are influenced by environmental concerns and constraints also influence USACE HQ and leadership-specifically, through environmental windows that restrict Nav O\&M. Thus, the relationship between external stakeholders, environmental concerns and constraints, and USACE HQ and leadership is likely the weak or strained relationship in the social system (Rogers 2003) that impedes innovations. The USACE employees interviewed expressed that their relationship with external stakeholders often hinders innovation; redefining this relationship will improve the rate of dredging innovation adoption.

We recommend that USACE carry out this redefinition of its place in the social system by making small changes to its communication channels that will produce a payoff when the innovation reaches the persuasion phase. 
Educate the public on dredging in a general sense, for example, and introduce all stakeholders to innovations as they are developing in the lab or field. As discussed in section 3, many interviewees mentioned that external stakeholders (including the public) and local governments influence USACE HQ and leadership. USACE can use this influence to its advantage through increasing public outreach via mass media, a useful technique discussed by the innovation diffusion theory (Rogers 2003; Sundstrom 2016; Clarke et al. 2016; Mannan et al. 2017). Mass media outreach, such as social media accounts and posts, as well as an actively updated public-facing website, should push the navigation program to implement innovations at a faster rate. This outreach is especially true in the case where a localized problem directly impacts the public and the public is aware of tools developed by USACE and its partners that will solve the problem if adopted. Public sentiment is often critical to innovation dissemination (Koski 2010). For instance, citizens and workers in the Long Beach Island, New Jersey, area showed a vested interest in dredging and storm management projects following Hurricane Sandy, as these USACE projects affected the local economy and future storm resilience (Radel 2017; Rochette 2014). Public sentiment helped approve the implementation of the MURDEN dredge, which provides increased capacity, allowing USACE to dredge more in shorter periods of time (Rochette 2014).

In addition to improving the strength and reach of communication channels with the public, USACE should push for more personal, face-to-face meetings with key dredging decision makers, like navigation program managers and contractors. One interviewee mentioned that USACE research and development innovations are often posted on the website with limited further promotion or transition support, which limits the likelihood that many innovations will be implemented. Innovations are more likely to be adopted by USACE through face-to-face meetings designed to advocate the use of the technology, particularly if the individuals presenting the innovation are considered experts known to navigation program team members. Rogers (2003) found that when a subjective evaluation of a new idea is presented by another individual, that individual is more likely to influence the first individual during the attitude stage.

\subsection{Social system}

Beyond bolstering communication channels, USACE can rework its relationships in the larger, complex social structure surrounding dredging. 
Numerous interviewees acknowledged the successes of local USACE districts, claiming that USACE's local districts are effective at interacting with local stakeholders. The local districts should continue to engage with the public and consider public opinion during the development of innovations, as public needs and opinions often push the navigation program to adopt an innovation. One interviewee recognized the importance of "having local citizenry, looking at what the Corps wants to do as far as an ecosystem approach," noting also that "it's [USACE] got to have a listening mode." However, while the USACE often succeeds at the district level, the districts' successes are disjointed and inconsistent. According to an interviewee, USACE "innovates well in pockets. With an organization as big as the Corps, you'll have leaders, laggards, and those in the middle." Another interviewee claimed that the disparity between districts "creates some awkward bidding climates." Therefore, USACE innovations may not reach broad implementation because the navigation program suffers from the "white flag of empowerment where each district has its own opportunity to execute in its own way and it has a tendency in some districts to stagnate the potential for innovation," as one interviewee phrased it. The inconsistencies between districts provide an opportunity for USACE to unite and strengthen its internal district network by introducing innovations and creating an open communication environment, where the districts discuss the benefits of certain innovations, so that different districts fully realize how implementing an innovation could benefit their navigation operations. There is an apparent need to "try to figure out how to take those that are leading and to share those successes, good best practices, and to implement them more broadly across the Corps," according to an interviewee. Thus, USACE could develop intermediary programs that augment or enhance current communities of practice and serve to unite districts while ensuring innovations are implemented more robustly.

Additionally, USACE should seek solutions that cover a wider range of topics than the barriers (that is, cost, time, and environmental constraints) that interviewees repeatedly emphasized. Dredging innovation is an interdisciplinary problem and should be perceived as such. Increasing collaboration and sharing resources between USACE, external stakeholders, and leadership in non-USACE organizations will help converge innovative ideas and work around current restrictions (Linkov, Wood, and Bates 2014). Bringing together the skill sets of stakeholders can occur through knowledge transfer activities such as partnerships, conferences, and sym- 
posia (Taylor 2003). Collaboration is necessary given how infrequently interviewees mentioned notions of systems and processes, science and technology, and mental models as depicted on the final expert model. Promoting innovative partnerships, knowledge dissemination, and new concepts and tools could overcome barriers and persuade external stakeholders and leadership in non-corps organizations to adopt or accept dredging technologies. Multiple interviewees, in the words of one interviewee, expressed a need to "try to bring a more collaborative approach to the environmental issues and opportunities that the dredge material and the maintenance of those in navigation channels provides to help achieve what these stakeholder centric goals and objectives are for their ecosystem." In order for USACE innovations to be widely adopted, it would be beneficial to increase communication and collaboration not only between USACE districts but also between USACE research and development, the navigation program, and external stakeholders such as contractors, regulatory and environmental agencies, and non-USACE government agencies. Those interviewed expressed that they thought "the Corps would benefit if they would be a little bit flexible to having other outside experts influence perhaps the ways jobs are designed" and that "communication access is critical both for the people that are going to do the work in the industry but also for the stakeholders and those that have a vested interested in it." USACE research and development could be at the forefront of increasing social systems networks and communication channels through knowledge transfer activities, which could catalyze innovation implementation.

Increasing collaboration will strategically place USACE in the social structure that currently restricts it. Further, increasing collaboration will help USACE understand ways to work with and around-rather than againstenvironmental constraints and the additional barriers it entails (that is, political concerns, high operation costs, and time restrictions). All cohorts of interviewees acknowledged environmental concerns and constraints, which reinforces that this node may be the central barrier for all stakeholders. In their study of innovation in sulfur dioxide management, Taylor et al. (2003) found that environmental regulations have as great an effect on innovation as market forces do. For innovators and early adopters, the number of patents (innovations) was bolstered by regulations. Regulations (barriers) proved to increase the number of new innovations present for adoption. Should the innovation trend seen in Taylor et al.'s case study apply to dredging innovation, it is possible for USACE to increase innovation while working within environmental regulations and constraints. Taking 
into account the possibility to collaborate and combine ideas with external stakeholders, the environmental regulations will incentivize innovation by inducing constraints that can only be addressed through cross-discipline collaboration.

These innovations should be compatible with and possess some relative advantage to what is currently on the market, given the importance of these factors in innovation diffusion (Lovejoy et al. 2009). In their collaborations, USACE should highlight the applicability and utility of dredging innovations-especially if they can be paired with or against existing technology.

\subsection{Decision model}

Using the literature review, government report review, and derived final expert mental model, we have developed a simple decision model designed to evaluate the extent to which a research program has established an effective innovation transition strategy (figure 8). Decision makers can use this model as a conceptual design tool to consider the relative effectiveness of technology transfer strategies or new communication and education initiatives. The model scores alternative strategies on a scale [0.1], with higher scores associated with strategies that are more likely to be effective. This top-level objective is broken into criteria and subcriteria that describe the different functions an effective strategy requires. At the bottom level of the tree are metrics that assess specific aspects of measurable strategies. These measurements occur in natural units (for example, number of hits on an internet press release) and are then normalized across alternatives from [0.1] using a value function. These normalized scores are then rolled up the tree by computing a weighted average, where numeric weights express a decision maker's expectations as to which components of an innovation transition strategy are more important or would be more effective for the specific technology or transition context. For more detailed information on decision analysis methods, including information on techniques for constructing models and developing weights and scores, please refer to Belton and Steward (2002) or Linkov et al. (2021).

In sum, innovation implementation is the end point of our decision model, what we call effective innovation transition strategy. Beginning with the action nodes on the far right, the decision model outlines actions that will help USACE open and improve communication and restructure its place in 
the social system. In achieving these two goals, USACE should see more of its innovations effectively transition to field use.

By reshaping USACE's innovation diffusion strategy to include some of these criteria, decision makers and other stakeholders will be better able to forecast which future actions will succeed.

Figure 8. Decision model for effective innovation transition strategy designed for USACE.

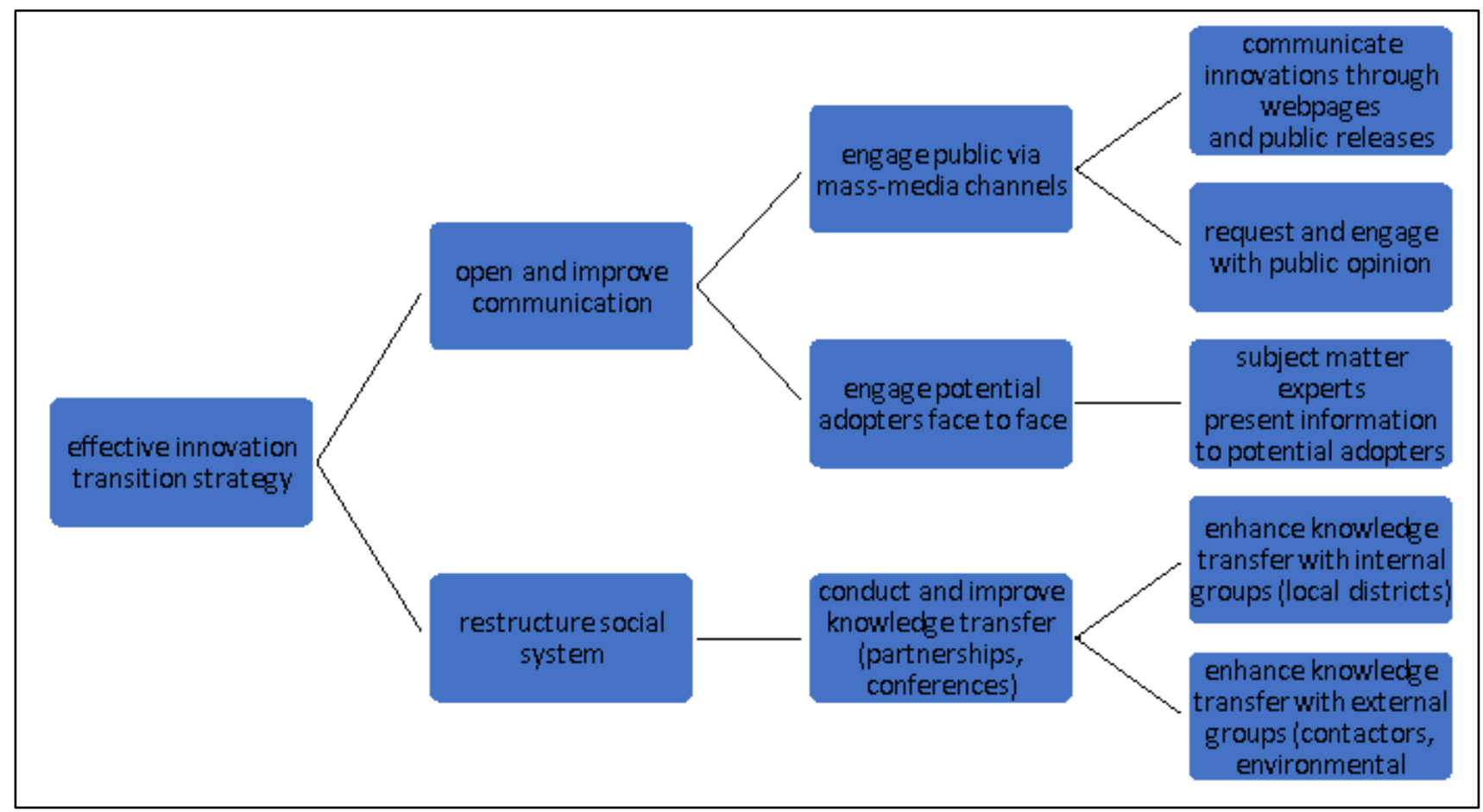

\subsection{Further considerations for innovation within USACE}

In the present study we concentrated on navigation dredging as a specific problem context for considering needs and opportunities related to practices either contributing to or hindering innovation. We chose this context because waterway management represents a substantial portion of USACE activities, and we believe the framework is applicable to other mission areas and projects within USACE. Ideally, this framework will enable discovery and improve understanding of opportunities for innovation diffusion and technology transfer around USACE as well as point the way towards future avenues of research into universals regarding the innovation culture at USACE. Once applied to several mission areas within USACE, common problems, needs, trends, and potential solutions will become clear across 
the organization. In this way, we advocate a practice-as-research approach, applying our framework to existing problems and adjusting as necessary. The results of a broader evaluation of innovation practice will provide the basis for an enterprise-level approach to process improvement in the innovation diffusion and development space within USACE. 


\section{References}

American Society for Engineering Education. 2017. Infrastructure Report Card: Ports. Retrieved 7 June 2017 from https://www.infrastructurereportcard.org/wpcontent/uploads/2017/o1/Ports-Final.pdf.

AtKisson, Alan. 1991. "The Innovation Diffusion Game: A tool for encouraging participation in positive cultural change - or for doing something different at your next party." Making it Happen IC\#28, Spring 1991. Context Institute. Retrieved on 7 June 2017 from http://www.context.org/iclib/ic28/atkisson/.

Atman, Cynthia J., Ann Bostrom, Baruch Fischhoff, and M. Granger Morgan. 1994. "Designing Risk Communications: Completing and Correcting Mental Models of Hazardous Processes, Part I.” Risk Analysis 14(5): 779-788.

Becker, Sascha O.; Pfaff, Steven; Yuan Hsiao and Jared Rubin. 2019. "Ideological Entrepreneurs and the Diffusion of Radical Innovation: Martin Luther's Personal Ties and the Spread of the Early Reformation.” https://www.eh.net/eha/wpcontent/uploads/2019/o6/Rubin.pdf

Belton, Valerie, and Theodor Stewart. 2002. Multiple Criteria Decision Analysis: An Integrated Approach. Springer Science \& Business Media.

Bostrom, Ann, M. Granger Morgan, Baruch Fischhoff, and Daniel Read. 1994. "What do people know about global climate change? 1. Mental models." Risk Analysis 14(6): 959-970.

Bridges, Todd S., Daniel Kovacs, Matthew D. Wood, Kelsie Baker, Gordon Butte, Sarah Thorne, and Igor Linkov. 2013. "Climate Change Risk Management: A Mental Modeling Application.” Environment Systems and Decisions 33 (3): 376-390.

Clarke, T. B., Murphy, J., \& Adler, J. 2016. "Celebrity Chef Adoption and Implementation of Social Media, Particularly Pinterest: A Diffusion of Innovations Approach.” International Journal of Hospitality Management 57: 84-92. https://doi.org/10.1016/j.ijhm.2016.06.004

Collier, Z. A., Trump, B. D., Wood, M. D., Chobanova, R., and Linkov, I. 2016. "Leveraging Stakeholder Knowledge in the Innovation Decision Making Process." International Journal of Business Continuity and Risk Management 6(3): 163181. https://doi.org/10.1504/IJBCRM.2016.078987

Daley, Dorothy M., and James C. Garand. 2005. "Horizontal Diffusion, Vertical Diffusion, And Internal Pressure in State Environmental Policymaking, 1989-1998.” American Politics Research 33 (5): 615-644.

Dickerson, Dena D., Kevin J. Reine, and Douglas G. Clarke. 1998. Economic Impacts of Environmental Windows Associated with Dredging Operations. WES-TN DOER-E3. Vicksburg MS: Army Engineer Waterways Experiment Station.

Dredging Operations Technical Support Program. 2017. "Dredging Resources - DOTS Webinar Archive.” p 17. https://dots.el.erdc.dren.mil/webinars5.html 
Goodman, Leo A. 1961. "Snowball Sampling." The Annals of Mathematical Statistics. 148-170.

Gray S.A., Zanre E., Gray S.R.J. 2014. Fuzzy Cognitive Maps as Representations of Mental Models and Group Beliefs. In: Papageorgiou E. (eds) Fuzzy Cognitive Maps for Applied Sciences and Engineering. Intelligent Systems Reference Library, Vol. 54. Springer, Berlin, Heidelberg.

Halbrendt, J., Gray, S. A., Crow, S., Radovich, T., Kimura, A. H., Tamang, B. B. 2014. "Differences in farmer and expert beliefs and the perceived impacts of conservation agriculture." Global Environmental Change 28: 50-62. doi:10.1016/j.gloenvcha.2014.05.001.

Hill, Stephen D., and Dixon Thompson. 2006. "Understanding managers' views of global environmental risk.” Environmental Management 37 (6): 773-787.

Huang, Ronggui. 2016. RQDA: R-based Qualitative Data Analysis. R package version o.28. URL http://rqda.r-forge.r-project.org/.

Hubbard, Susan M., and Susan W. Hayashi. 2003. "Use of diffusion of innovations theory to drive a federal agency's program evaluation.” Evaluation And Program Planning 26 (1): 49-56.

Jones, Natalie A., Helen Ross, Timothy Lynam, Pascal Perez, and Anne Leitch. 2011. "Mental Models: An Interdisciplinary Synthesis of Theory and Methods." Ecology and Society 16 (1).

Kane, Mary, and William MK Trochim. 2007. Concept Mapping for Planning and Evaluation. Vol. 50. Thousand Oaks, CA: Sage Publications.

Keisler, J. M., Collier, Z. A., Ayyub, B. M., Dempwolf, C. S., Gibson, J. M., Porter, A. L., Schweizer, V. J., Thorisson, H., Wang, L., Ye, M., Lambert, J. H. and Linkov, I. 2020. Modeling and Analytics to Support Emerging International Innovation Partnerships. IEEE Engineering Management Review 48(2): 54-64. doi: 10.1109/EMR.2020.2989391.

Klasa, K., Trump, B. D., Linkov, I., and Lambert, J. H. 2020. Identifying New Partnerships for Innovation: Governance and Policy Challenges. IEEE Engineering Management Review 48(2): 26-38. doi: 10.1109/EMR.2020.2989263”

Koski, Chris. 2010. "Greening America's Skylines: The diffusion of low-salience policies." Policy Studies Journal 38 (1): 93-117.

Kovacs, Daniel, Sarah Thorne, and Gordon Butte. 2017. "Influence of the CHEMM Tool on Planning, Preparedness, and Emergency Response to Hazardous Chemical Exposures: A Customized Strategic Communications Process Based on Mental Modeling." In Mental Modeling Approach, pp. 105-131. Springer, New York, NY.

Linkov, I.; Moberg, E., Trump, B., Yatsalo, B., Keisler, J. M. 2011. Multi-Criteria Decision Analysis: Case Studies in Engineering and the Environment. 2nd Edition. CRC Press.: Boca Raton, FL. 
Linkov, Igor, Matthew Wood, and Matthew Bates. 2014. "Scientific Convergence: Dealing with the Elephant in the Room." 10539-10540.

Lovejoy, Travis I., Petya D. Demireva, Jessica L. Grayson, and John R. McNamara. 2009. "Advancing the Practice of Online Psychotherapy: An Application of Rogers' Diffusion of Innovations Theory." Psychotherapy: Theory, Research, Practice, Training 46 (1): 112.

Lowe, Thomas D., and Irene Lorenzoni. 2007. "Danger is All Around: Eliciting Expert Perceptions for Managing Climate Change Through a Mental Models Approach.” Global Environmental Change 17 (1): 131-146. https://doi.org/10.1016/j.gloenvcha.2006.05.001

Mitchell, N., and Heather Nachtmann. 2016. Optimal Dredge Fleet Scheduling within Environmental Work Windows. Presentation at the National Academy of Sciences, Committee on the Marine Transportation System, 21 June 2016. Retrieved 7 June 2017 from:

http://onlinepubs.trb.org/onlinepubs/conferences/2016/CMTS/Presentations/6 8.NedMitchell.pdf .

Morgan, M. Granger, Baruch Fischhoff, Ann Bostrom, and Cynthia J. Atman. 2002. Risk Communication: A Mental Model Approach. Cambridge University Press.

National Environmental Policy Act of 1969, 42 USC. $\$ 4321$ et seq. 2018. Title 42 The Public Health and Welfare. Washington, DC: Government Printing Office. https://www.govinfo.gov/content/pkg/USCODE-2018-title42/pdf/USCODE2018-title42-chap55.pdf.

Palmgren, Claire R., M. Granger Morgan, Wändi Bruine de Bruin, and David W. Keith. 2004. "Initial Public Perceptions of Deep Geological and Oceanic Disposal of Carbon Dioxide." Environmental Science \& Technology 38(24): 6441-6450.

Reine, Kevin J., Dena D. Dickerson, and Douglas G. Clarke. 1998. Environmental Windows Associated with Dredging Operations. WES-TN DOER-E2. Vicksburg MS: Army Engineer Waterways Experiment Station.

Sundstrom, Beth. 2016. "Mothers “Google It Up:” Extending Communication Channel Behavior in Diffusion of Innovations Theory." Health Communication 31(1): 91101. doi:10.1080/10410236.2014.936339.

US Army Corps of Engineers. 1983. Dredging and Dredged Material Disposal. EM 11102-5025. Washington DC: US Army Corps of Engineers. https://apps.dtic.mil/dtic/tr/fulltext/u2/a365282.pdf.

US Army Corps of Engineers. (1987a). Beneficial Uses of Dredged Material. EM 1110-25026. https://www.publications.usace.army.mil/LinkClick.aspx?fileticket $=$ xOcejFNLU9I\%3d\&tabid $=16439 \&$ portalid $=76 \&$ mid $=43544$. 
US Army Corps of Engineers. (1987b). Confined Disposal of Dredged Material. EM 11102-5027. Washington, DC: US Army Corps of Engineers. https://www .publications.usace.army.mil/Portals/76/Publications/EngineerManuals /EM_1110-2-5027.pdf.

US Army Corps of Engineers. (1987c). Dredging and Dredged Material Management. EM 1110-2-5025. https://www.publications.usace.army.mil/LinkClick.aspx?fileticket $=x O c e j F N L U 9 I \% 3 d \&$ tabid $=16439 \&$ portalid $=76 \&$ mid $=43544$.

US Army Corps of Engineers. 1996. Navigation and Dredging Operations and Maintenance Policies. ER 1130-2-520. https://www.publications.usace.army.mil /Portals/76/Publications/EngineerRegulations/er_1130-2-520.pdf.

US Army Corps of Engineers. 2015. Dredging and Dredged Material Management. EM 1110-2-5025. https://www.publications.usace.army.mil/Portals /76/Publications/EngineerManuals/EM_1110-2-5025.pdf.

US Army Corps of Engineers. 2017. President's fiscal 2017 budget for US Army Corps of Engineers Civil Works. Retrieved 8 June 2017 from http://www.usace.army.mil/Media/Fact-Sheets/Fact-Sheet-ArticleView/Article/651818/presidents-fiscal-2017-budget-for-us-army-corps-ofengineers-civil-works/

US Environmental Protection Agency and US Army Corps of Engineers. 2007. The Role of the Federal Standard in the Beneficial Use of Dredged Material from US Army Corps of Engineers New and Maintenance Navigation Projects: Beneficial Uses of Dredged Materials. https://erdc-library.erdc.dren.mil/jspui/handle/11681/14484

US Government Accountability Office. 2003. Effects of Restrictions on Corps' Hopper Dredges Should be Comprehensively Analyzed. Report to Congressional Committees. GAO-03-382: Published: Mar 31, 2003. Publicly Released: Mar 31, 2003. https://www.gao.gov/products/GAO-03-382.

US Government Accountability Office. 2014. Actions Needed to Further Improve Management of Hopper Dredging. Report to the Ranking Member, Subcommittee on Water Resources and Environment, Committee on Transportation and Infrastructure, House of Representatives. GAO-14-290. Published: April 10, 2014. Publicly Released: May 12, 2014.

US Government Accountability Office. (2015). Technology Transfer: Federal Laboratory Consortium Should Increase Communication with Potential Customers to Improve Initiatives. Report to Congressional Requesters. GAO-15-127. Published: April 10, 2014. Publicly Released: May 12, 2014.

Read, Daniel, Ann Bostrom, M. Granger Morgan, Baruch Fischhoff, and Tom Smuts. 1994. "What Do People Know About Global Climate Change? 2. Survey studies of educated laypeople.” Risk Analysis 14(6):971-982. https://doi.org/10.1111/j.1539-6924.1994.tbooo66.x

Rogers, Everett M. Diffusion of Innovations. 2010. New York: Simon and Schuster.

Stewart, John, and Gordon Butte. 2017. "The Chamber of Mines of South Africa Leading Practice Adoption System.” In Mental Modeling Approach, pp. 133-151. New York, NY: Springer. 
Taylor, Margaret R., Edward S. Rubin, and David A. Hounshell. 2003. "Effect of Government Actions on Technological Innovation for SO2 Control." Environmental Science \& Technology 37(20): 4527-4534. https://doi.org /10.1021/eso34223b.

Wagner, Klaus. 2007. "Mental Models of Flash Floods and Landslides." Risk Analysis: An International Journal 27(3): 671-682.

Wani, T. A. and Ali, S. W. 2015. "Innovation Diffusion Theory: Review and Scope in the Study of Adoption of Smartphones in India." Journal of General Management Research 3(2): 101-118.

Wood, Matthew D., Ann Bostrom, Matteo Convertino, Daniel Kovacs, and Igor Linkov. 2012. "A Moment of Mental Model Clarity: Response to Jones et al. 2011." Ecology and Society 17 (4).

Wood, Matthew, Daniel Kovacs, Ann Bostrom, Todd Bridges, and Igor Linkov. 2012. "Flood Risk Management: US Army Corps of Engineers and layperson perceptions." Risk Analysis: An International Journal 32 (8): 1349-1368.

Wood, Matthew D., Sarah Thorne, Daniel Kovacs, Gordon Butte, and Igor Linkov. 2017. Mental Modeling Approach: Risk Management Application Case Studies. 1133. New York: Springer-Verlag.

Zanello, Giacomo, Xiaolan Fu, Pierre Mohnen, and Marc Ventresca. 2016. "The Creation and Diffusion of Innovation in Developing Countries: A Systematic Literature Review." Journal of Economic Surveys 30 (5): 884912. doi: $10.1111 /$ joes. 12126

Zhang, H. and Vorobeychik, Y. 2019. "Empirically Grounded Agent-Based Models of Innovation Diffusion: A Critical Review." Artificial Intelligence Rev 52: 707-741. doi:10.1007/s10462-017-9577-z. 


\section{Appendix A: GAO Reports}

Fifty-eight GAO reports were collected from the following agencies and departments, as their missions are similar to that of USACE:

- $\quad$ Environmental Protection Agency

- $\quad$ Federal Emergency Management Agency

- $\quad$ National Institute of Standards \& Technology

- National Oceanic and Atmospheric Administration

- $\quad$ National Parks Service

- $\quad$ US Coast Guard

- US Department of Agriculture

- $\quad$ US Department of Energy

- US Department of Transportation

- $\quad$ US Forest Service

- $\quad$ US Geological Survey 


\section{Appendix B: Category Definitions}

\begin{tabular}{|c|c|}
\hline Category Name & Definition \\
\hline $\begin{array}{l}\text { Collaboration and } \\
\text { Communication }\end{array}$ & $\begin{array}{l}\text { the ability to effectively collaborate with external } \\
\text { groups (other agencies, state governments, or } \\
\text { privately owned companies) as well as internal } \\
\text { collaboration and communication efforts within } \\
\text { the agency itself }\end{array}$ \\
\hline Planning & $\begin{array}{l}\text { the ability to set clear and attainable timelines } \\
\text { and to anticipate future steps needed }\end{array}$ \\
\hline Data Collection & $\begin{array}{l}\text { the ability to collect data consistently and } \\
\text { adequately for future use }\end{array}$ \\
\hline Hierarchy & $\begin{array}{l}\text { the presence of a clear chain of command, with a } \\
\text { strong leadership role and known and understood } \\
\text { lines of communication }\end{array}$ \\
\hline Transparency & $\begin{array}{l}\text { the clarity and openness of the decision-making } \\
\text { process }\end{array}$ \\
\hline Defined Goals & the ability to clearly state quantifiable objectives \\
\hline Cost Estimate & the ability to accurately estimate costs \\
\hline Data Analysis & $\begin{array}{l}\text { the ability to effectively and efficiently analyze } \\
\text { data }\end{array}$ \\
\hline Staff Education & $\begin{array}{l}\text { the ability to recruit and retain personnel with the } \\
\text { correct training necessary to complete tasks }\end{array}$ \\
\hline
\end{tabular}




\section{Appendix C: Interview Protocol}

\section{Solicitation}

Hi, my name is <name>, I am a researcher with the Corps of Engineers Research \& Development Center, Environmental Lab. I am calling for a project funded by the Dredging Operations \& Environmental Research program that is investigating the Corps' current approach to Navigation Operations \&Maintenance and ways that it can be improved. We are interviewing individuals both within and outside the Corps who are familiar with the Navigation Operations \& Maintenance process.

I'm calling to ask if you are interested in participating in a research interview. [Brief statement why this particular individual was asked to participate.] Our conversation should take about 40 minutes and requires only some general knowledge of the Corps dredging processes, especially those related to the Army Corps of Engineers' Navigation Operations \& Maintenance Program. Would you be interested in participating?

If "no": Thank you for your time.

If "yes": Would you like to do the interview now or is there a time that works better for you?

If now: [Proceed to the Introduction below.]

If later: [Arrange a day and time and call back later.]

\section{If calling back at a scheduled time:}

[Introduce yourself]. As I mentioned when I set up the interview we're talking to people within and outside the organization about the Army Corps of Engineers' current approach to Navigation Operations \& Maintenance including ways to improve it. As I mentioned our conversation should take about 40 minutes.

\section{Introduction}

I have some questions to help guide our discussion, but please feel free to raise any topic that comes to mind as we go along. There are no right or 
wrong answers and all of the comments you provide will add value to our research. I assure you that what you say will be kept confidential to our research team, and you will not be identified in the findings.

Before we start, I'd like your permission to record our conversation in order to prepare better notes afterwards. But as I said, everything you say will be kept confidential. May we proceed on that basis? Thank you.

We'll start by talking generally about Corps business processes especially those related to Army Corps of Engineers' Navigation Operations \& Maintenance Program and then transition to different ways these processes might be improved. When I say Navigation, I am referring to those activities which permit, support, and/or facilitate maritime activities on both inland and coastal bodies of water. We will finish up with a few rating questions about the current Navigation process and a few questions about your role within it.

Please remove solicitation page when sending in shortnotes. 
Overcoming Barriers to Innovation Mental Models Research Protocol

Please send completed notes (with solicitation page deleted) to matthew.d.wood@usace.army.mil .

Please use the following format for shortnote filename, starting with the interview code w/o spaces.

Interview Code/Filename: [XX\#\# BARRIERS MM.doc]

(your initials and index number, project name, for example, ARo1 BARRIERS MM.doc)

Record the interview code twice in the spaces below.

, Interview Code . [ARo1]

- [ARo1]

Interview Date

, $x$ Date $[\mathrm{mm} / \mathrm{dd} / \mathbf{y y}]$

Length in Minutes

, $\quad$ Minutes [\#\#] 
Interviewer/Note taker comments on interview:

Please provide a brief summary of the interview highlights.

Interview Questions

Drivers

o1. Thinking about it at the most general level, what are the most important factors from your perspective that drive or influence the Corps' Navigation O\&M activities?

- Can you think of anything else?

\section{o1. [response]}

02. What are some key drivers from your perspective that are internal to the Corps and influence Navigation O\&M, such as its Mission \& Mandate?

- What about the Federal Standard plan or cost mandate?

- What about the mandate to promote national security (for example, dredging for Navy ports/bases)?

- What about value to the nation?

- What about sponsors/partners in dredging?

\section{o2. [response]}

03. What are some key drivers from your perspective that are external to the Corps which influence Navigation O\&M?

- What about historic activity at the site/channel? 
- What about weather \& climate?

- What about land use?

o3. [response]

\section{People \& Organizations}

04. At the most general level, who are the different people or organizations from your perspective whose activities or perceptions influence how the Corps conducts Navigation O\&M activities?

- How do their activities or perceptions influence Navigation O\&M activities?

\section{o4. [response]}

05. From your perspective, what aspects of the current Navigation O\&M process work well and help the Corps to successfully achieve its mission?

\section{o5. [response]}

o6. From your perspective, what opportunities for improvement exist with current Navigation O\&M processes where mission success is currently impeded? 


\section{o6. [response]}

07. From your perspective, who are the strategic partners that are instrumental in supporting or advancing ${ }^{\mathbf{1}}$ the Navigation O\&M process? How do they influence the process?

\section{- What about Corps HQ and leadership?}

- What about the role of research at groups like ERDC, IWR, etc.?

- What about leadership in other non-Corps organizations with which the Corps frequently works, for example, EPA, state agencies, etc.

- What about senior scientists and technical directors in other nonCorps organizations with which the Corps frequently works?

\section{o7. [response]}

o8. From your perspective are there key technologies, tools, or practices that you use in your current role related to the Navigation O\&M process?

- How do you use it?

- How much or how often do you use it?

- If no, are there technologies, tools, or practices that you are aware of? How are they used?

1. For any named entity, we made sure to understand whether the role is current support, advance/improvement, both, or something else that is related. 


\section{o8. [response]}

o9. From your perspective are there key technologies, tools, or practices which you need to be more effective in your current role related to the Navigation O\&M process?

\section{- What of these exist but are currently unavailable to you?}

- What of these do not yet exist and should be developed by the Corps or others?

- If no, are there technologies, tools, practices that you are aware of which would make those with roles related to Navigation O\&M more effective?

\section{o9. [response]}

\section{Innovation}

10. We are now going to transition to a set of questions on the Corps and its approach to innovation. When I say innovation, I mean the process of developing and/or incorporating new tools ${ }^{2}$, technologies 3 , and practices 4 that improve the way in which the Corps accomplishes its mission. From your perspective and at a general level, how well does the Corps innovate?

- Why do you say that?

2 A practical means or methodology of carrying out a process or fulfilled a goal (for example, an artifact like the Data Quality Management (DQM) system).

3 A practical theory or concept that could be applied; the application of some scientific knowledge or design principle (for example, building with nature as seen in the Sand Engine in the Netherlands (http://www.dezandmotor.nl/en-GB/).

4 Social, culture, or professional behaviors/procedures (For example, On Barren Island in the Chesapeake Bay, community volunteers were asked to help plant vegetation that keeps deposed sediment in place and creates marsh habitats (http://el.erdc.usace.army.mil/dots/webinar/13Sep18-

DOTS_Beneficial\%20Use\%20of\%20DM.pdf)). 


\section{0. [response]}

11. From your perspective, how well does the Corps innovate with respect to its Navigation O\&M process specifically (for example, how the Corps does business, engages with others within \& outside the Corps, etc.)?

- Why do you say that?

\section{1. [response]}

12. How well does the Corps innovate in technical aspects of the Navigation O\&M program from your perspective, like incorporating new tools and technologies?

\section{2. [response]}

13. How well does the Corps disseminate innovations that facilitate the Navigation O\&M process from your perspective, both internally across its operating units and externally?

\section{3. [response]}

14. What role do sources outside of the Corps play in Navigation O\&M innovation from your perspective?

- What is the role of contractors and other work partners?

- What is the role of external research \& development organizations?

- What is the role of other government organizations?

- What is the role of nonprofit organizations (for example, Nature Conservancy) 


\section{4. [response]}

15. Can you identify future opportunities to innovate from your perspective that can improve the current Navigation O\&M process, either in the near-term or long-term?

- What about at a conceptual level, that is, finding new technologies, solutions and ways of solving problems?

- What about with respect to tools that can improve the process?

- What about with respect to how the Corps engages internally with other Corps partners and external partners (for example, EPA, Resources for the Future)?

\section{5. [response]}

16. What do you feel is the Corps' opinion with respect to innovation in general? Is the Corps accepting or unaccepting of innovation from your perspective? Why/why not?

- What do you feel the Corps' opinion of innovation is with respect to the development \& use of tools and technologies?

- What do you feel their opinion of innovation is with respect to the development, dissemination, \& implementation of best practices?

\section{6. [response]}

\section{Barriers}

17. What are some of the barriers from your perspective that inhibit the ability of the Corps to innovate in the area of Navigation O\&M? In what way do these barriers inhibit innovation? 


\section{7. [response]}

17a. From your perspective, what is the influence of Corps and federal budgeting processes on the ability to innovate in Navigation O\&M from your perspective? In what way?

\section{7a. [response]}

17b. What is the influence of Corps leadership from your perspective on the ability to innovate in Navigation O\&M? In what way?

- What about leadership at headquarters?

- What about leadership inside the division \& districts?

- What about leadership within Corps Research \& Development programs (for example, DIG, DOER, DOTS)?

\section{7b. [response]}

17c. From your perspective, what is the influence of Corps project managers, engineers, and other implementing staff and their perceptions of the Navigation O\&M process on the ability to innovate in Navigation O\&M? In what way?

\section{7c. [response]}

17d. From your perspective, what is the influence of external stakeholders and their perceptions of the Navigation O\&M process on the ability to innovate in Navigation O\&M? In what way?

\section{- What about external stakeholders like other regulatory agencies?}


- What about local citizens?

- What about other groups?

\section{7d. [response]}

17e. What from your perspective is the influence of environmental concerns on the ability to innovate in Navigation O\&M? In what way?

\section{7e. [response]}

17f. What is the influence of project-specific characteristics (for example, dredged material type) from your perspective on the ability to innovate in Navigation O\&M?

- What contextual variables influence the ability to innovate?

- Are there specific contexts or project types where innovation is difficult?

- $\quad$ Are there specific contexts or project types where innovation is easy/easier?

\section{7f. [response]}

17g. From your perspective, are there any other types of influences that inhibit or enhance the ability for the Corps to innovate in Navigation O\&M?

\section{7g. [response]}


18. From your perspective, what opportunities exist currently for training or continuing education among the Corps workforce involved in Navigation O\&M?

- What is needed in terms of training and education?

- $\quad$ Are there ways which current opportunities could be improved or expanded?

- How could Corps employees involved in Navigation O\&M be encouraged to use these opportunities?

- $\quad$ Are there barriers that inhibit the ability of the workforce to improve their Navigation O\&M knowledge? What are these barriers?

\section{8. [response]}

19. Is there anything else that you think is important in improving the Corps' ability to improve or innovate in the area of Navigation O\&M?

\section{9. [response]}

\section{Rating items / closing}

Those are the main questions I had. In closing, I have a few demographic questions.

20. I am going to read out the different elements of the Navigation O\&M Process.

CORPS/INTERNAL INTERVIEWEES: For each one, please rate the extent of your involvement in this element as either: high involvement [h], modest involvement [m], little involvement [l], or no involvement [x] 
[k = don't know; na $=$ not asked/answered $]$

NON-CORPS/EXTERNAL INTERVIEWEES: For each one, please rate the extent to which you are familiar with each element as either: high familiarity [h], modest familiarity [m], little familiarity [l], or no familiarity $[\mathrm{x}]$

$[\mathrm{k}=$ don't know; na $=$ not asked/answered $]$

20a. Planning - those elements of the Corps responsible for pre-and-post authorization studies (for example, feasibility, and other similar study activities

\section{, Planning $[\mathbf{h} / \mathbf{m} / \mathbf{l} / \mathbf{x} / \mathbf{k} / \mathbf{n a}]$}

2ob. Engineering - those elements of the Corps responsible for the design of navigation channels, locks, and related infrastructure

\section{, Engineering $[\mathbf{h} / \mathbf{m} / \mathbf{l} / \mathbf{x} / \mathbf{k} / \mathbf{n a}]$}

20c. Operations-those elements of the Corps responsible for construction, operation, and maintenance of navigation projects, as well as related activities

\section{Operations [h/m/l/x/k/na]}

2od. Environmental-those elements of the Corps responsible for environmental restoration, remediation, cleanup, and protection activities

\section{, Environmental $[\mathbf{h} / \mathbf{m} / \mathbf{l} / \mathbf{x} / \mathbf{k} / \mathbf{n a}]$}


20e. Regulatory-those elements of the Corps responsible for permitting, compliance, and related activities

, Regulatory $[\mathbf{h} / \mathbf{m} / \mathbf{l} / \mathbf{x} / \mathbf{k} / \mathbf{n a}]$

21. INTERNAL: How many years have you worked for the Corps of Engineers?

EXTERNAL: How many years have you worked with the Corps of Engineers?

, yearsCorps [yearsCorps]

22. INTERNAL: How many years have you worked within your current job or role within the Corps?

EXTERNAL: How many years have you worked within your current job or role at your organization?

, yearsRole [yearsRole]

23. INTERNAL: Before working for the Corps 5 in your current role, what did you do? Was it with the Corps or another organization?

EXTERNAL: Before working for your current organization in your current role, what did you do? Was it with the Corps or another organization?

$\begin{array}{lll}, & \text { preRole } & \text { [preRole] } \\ , & \text { preOrg } & \text { [preOrg] }\end{array}$

5. Or alternative if not working in the Corps (that is, "Before working for your current organization in your current role..."). 
Those are all the questions that I had. You've been very helpful. Thank you for your time. [Interviewer, turn off recording here]

Note to Interviewer: If they have questions about the research tell them the results will be used to recommend improvements to the Navigation O\&M process, especially the process by which new techniques and technologies are integrated into current business practices. Highlights from this research will be shared with Corps personnel who have a role in the development, support, or implementation of new technologies and techniques.

If people have questions about ERDC-EL, or want to contact someone regarding the research, please forward them to Matt Wood, matthew.d.wood@usace.army.mil or 978.318.8793 (or take their number and have Matt contact them). 


\section{Appendix D: Code Definitions}

Table D-1. Nav 0\&M driver codes and their definitions.

\begin{tabular}{|l|l|}
\hline Code & Definition \\
\hline Mission \& Mandate & Expense associated with an initiative; financial constraints; standard or base plan \\
Political & Civil and military work; the federal standard \\
Historic Activity & Past maintenance schedule; other past projects \\
Weather \& Climate & Mentions of storms, flooding, sea level rise \\
Land Use & Agriculture, residential, or commercial land cover, regional sediment management \\
National Security & Dredging for navy ports and bases \\
Navigability of Rivers & Anything related to ease of access for dredging fleets or ease of dredging \\
\hline
\end{tabular}

Table D-2. Systems and processes codes and their definitions.

\begin{tabular}{|l|l|}
\hline Code & Definition \\
\hline Project-Partner & Partnerships or the need for a partnership without also mentioning innovation \\
Bidding Process & $\begin{array}{l}\text { Any reference to the USACE contract bidding process } \\
\text { Budget Cycle }\end{array}$ \\
$\begin{array}{l}\text { Any reference to the USACE budget cycle; key phases include OMB-ASA guidance, de- } \\
\text { velopment of program requirements, budget sent to army secretary, submission to } \\
\text { OMB, OMB passback, president's budget to Congress, Congressional hearings, appro- } \\
\text { priation bills, funding allocation }\end{array}$ \\
\hline
\end{tabular}


Table D-3. People codes and their definitions.

\begin{tabular}{|c|c|}
\hline Code & Definition \\
\hline USACE Research Groups & ERDC, IWR \\
\hline O\&M Personnel & $\begin{array}{l}\text { Section leads, PMs, planning and design, engineering, operations, environmen- } \\
\text { tal, regulatory, district commands }\end{array}$ \\
\hline Local Residents & Homeowners, business owners, recreations users, project users, harbor users \\
\hline External Stakeholders & $\begin{array}{l}\text { Shippers and cargo owners, NGOs, regulatory agencies, citizen groups, water- } \\
\text { shed associations, private conservations, ASBPA }\end{array}$ \\
\hline Project Partners & Partnerships or the need for a partnership without also mentioning innovation \\
\hline $\begin{array}{l}\text { Leadership in non-Corps } \\
\text { Orgs }\end{array}$ & $\begin{array}{l}\text { EPA and state agencies, senior scientists and technical directors, ports, water- } \\
\text { ways groups, sediment management agencies, permitting }\end{array}$ \\
\hline Corps HQ and Leadership & Project managers, engineers, and anyone affiliated with USACE's budget \\
\hline Contractors & USACE's contracting mechanism and the contractors participation in it \\
\hline
\end{tabular}

Table D-4. Science and technology codes and their definitions.

\begin{tabular}{|c|c|}
\hline Code & Definition \\
\hline DOER / DOTS / DIG & $\begin{array}{l}\text { Dredging Operations and Environmental Research (DOER) program, the } \\
\text { Dredging Operations Technical Support group (DOTS), or the Dredging In- } \\
\text { novations Group (DIG) }\end{array}$ \\
\hline $\begin{array}{l}\text { Regional Sediment Manage- } \\
\text { ment }\end{array}$ & Any mention of RSM \\
\hline Dredging Technologies & Technological improvements to dredging \\
\hline External Tech Developments & $\begin{array}{l}\text { Technologies developed from academia, industry, government labs, NGOs, } \\
\text { foreign sources }\end{array}$ \\
\hline RDC Partner Development & SERDP, PIANC, EcoShape \\
\hline Current ERDC Technologies & D2M2, SedMan, Silent Inspector or DQM, CPT \\
\hline Current External Technologies & LiDAR, AIS Tracking, GIS, and other technologies developed outside USACE \\
\hline Best Practices & Ideal behaviors \\
\hline
\end{tabular}


Table D-5. Mental models codes and their definitions.

\begin{tabular}{|l|l|}
\hline \multicolumn{1}{|c|}{ Code } & Definition \\
\hline Innovative Partnerships & Mentions needing a partnership as a prerequisite for innovation \\
Innovative Concepts & $\begin{array}{l}\text { Willingness to accept innovation communication; mention of how quickly new in- } \\
\text { novations are spread } \\
\text { Innovative Tools }\end{array}$ \\
$\begin{array}{l}\text { Organizational risk tolerance, individual risk tolerance, the probability of innova- } \\
\text { tion adoption } \\
\text { Dredge Material and Type }\end{array}$ & \begin{tabular}{l} 
Any mention of dredging materials \\
\hline
\end{tabular}
\end{tabular}

Table D-6. Constraint codes and their definitions.

\begin{tabular}{|l|l|}
\hline Code & Definition \\
\hline Resource Constraints & $\begin{array}{l}\text { Anything that limits available resources or mentions limited re- } \\
\text { sources }\end{array}$ \\
Legislative and Regulatory Constraints & Legislation that impedes USACE's ability to innovate \\
Environmental Concerns and Constraints & Environmental factors that impedes USACE's ability to innovate \\
\end{tabular}




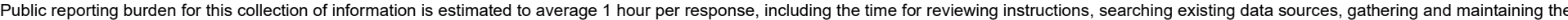

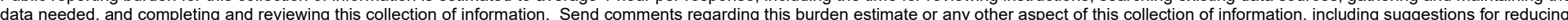

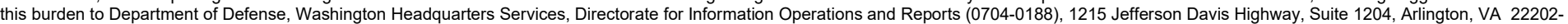

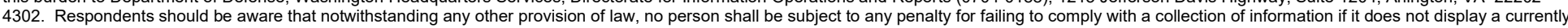
valid OMB control number. PLEASE DO NOT RETURN YOUR FORM TO THE ABOVE ADDRESS.
1. REPORT DATE (DD-MM-YYYY) September 2020 2. REPORT TYPE

\section{Final}

\section{TITLE AND SUBTITLE}

Barriers to Innovation in USACE

3. DATES COVERED (From - To)

5a. CONTRACT NUMBER

5b. GRANT NUMBER

5c. PROGRAM ELEMENT NUMBER

5d. PROJECT NUMBER

5e. TASK NUMBER

5f. WORK UNIT NUMBER

8. PERFORMING ORGANIZATION REPORT NUMBER

ERDC/EL TR-20-4

3909 Halls Ferry Road

Vicksburg, MS 39180

10. SPONSOR/MONITOR'S ACRONYM(S)

9. SPONSORING / MONITORING AGENCY NAME(S) AND ADDRESS(ES)

US Army Corps of Engineers

DOER Program

Washington, DC 20314

11. SPONSOR/MONITOR'S REPORT NUMBER(S)

\section{DISTRIBUTION / AVAILABILITY STATEMENT}

Approved for public release; distribution is unlimited.

\section{SUPPLEMENTARY NOTES}

Under Funding Account Code U4368804, AMSCO Code 089500, "Mental Modeling Decision Tools"

\section{ABSTRACT}

The Dredging Operations and Environmental Research Program of the United States Army Corps of Engineers (USACE) develops new tools and practices to support the efficiency, effectiveness, and sustainability of navigation dredging operations and then implements these new approaches (that is, innovations). We analyzed the innovation process to increase the adoption and implementation of new approaches and techniques. We then created a literature review of innovation diffusion theories and developed a mental model that identifies the actual and perceived barriers to innovation diffusion in USACE through a case study of its Navigation Program. We built the final expert mental model using interviews with 25 subject matter experts familiar with the program's processes and external stakeholders. Interviewees reported environmental and budgetary constraints, time restrictions, and politics as the most common barriers to dredging innovation, including those based on the perceptions and beliefs of stakeholders rather than hard engineering or policy constraints (herein cognitive barriers). We suggest overcoming these barriers through changes in communication channels and social systems, such as public outreach through social media channels; interpersonal face-to-face meetings with decision makers; internal collaboration between local USACE districts and external collaboration with outside stakeholders, such as contractors and environmental regulators.

\section{SUBJECT TERMS}

Dredging; Technological innovations; Organizational change; Diffusion of innovations; United States. Army. Corps of Engineers--Civil functions

\begin{tabular}{|l|l|l|c|c|c|}
\hline \multicolumn{2}{|l|}{ 16. SECURITY CLASSIFICATION OF: } & $\begin{array}{c}\text { 17. LIMITATION } \\
\text { OF ABSTRACT }\end{array}$ & $\begin{array}{c}\text { 18. NUMBER } \\
\text { OF PAGES }\end{array}$ & $\begin{array}{c}\text { 19a. NAME OF RESPONSIBLE PERSON } \\
\text { Igor LinkOV }\end{array}$ \\
\hline $\begin{array}{c}\text { a. REPORT } \\
\text { Unclassified }\end{array}$ & $\begin{array}{c}\text { b. ABSTRACT } \\
\text { Unclassified }\end{array}$ & $\begin{array}{c}\text { c. THIS PAGE } \\
\text { Unclassified }\end{array}$ & SAR & $\begin{array}{c}\text { 19b. TELEPHONE NUMBER } \\
\text { (include area code) } \\
(617) 233-9869\end{array}$ & 71 \\
\hline
\end{tabular}

